\title{
POLITICAL ECONOMY OF ANTIDUMPING AND SAFEGUARDS IN ARGENTINA
}

\author{
Julio J. Nogués* \\ Elías Baracat**
}

\begin{abstract}
* Professor of International Trade Policies and Institutions, Universidad Di Tella (jnogues@infovia.com.ar ).
\end{abstract}

\author{
** Independent consultant and former President of the Comisión Nacional de \\ Comercio Exterior (eliasbaracat@uolsinectis.com.ar ).
}

\begin{abstract}
World Bank Policy Research Working Paper 3587, May 2005
The Policy Research Working Paper Series disseminates the findings of work in progress to encourage the exchange of ideas about development issues. An objective of the series is to get the findings out quickly, even if the presentations are less than fully polished. The papers carry the names of the authors and should be cited accordingly. The findings, interpretations, and conclusions expressed in this paper are entirely those of the authors. They do not necessarily represent the view of the World Bank, its Executive Directors, or the countries they represent. Policy Research Working Papers are available online at http://econ.worldbank.org.
\end{abstract}

\footnotetext{
- We want in the first place to thank J. Michael Finger for his insightful comments to previous drafts of this paper which guided us in writing the story presented here. Other comments, particularly those by Pablo Sanguinetti, Diana Tussie and other participants at the Seminar on: "Uso de Salvaguardias y Antidumping en América Latina" (Buenos Aires, May 24-25, 2004), also enriched the paper. Several public officials have been generous in taking time to meet with the authors and prepare statistical information. They include: Lic. Guillermo Feldman, Undersecretary of Gestión Comercial Externa; Ms. Elena Di Vico President of the CNCE, and Ms. Valeria Raiteri, National Director of Competencia Desleal. Finally, we acknowledge the editorial work of Ms. María N. Gondell. In spite of all these contributions, we remain solely responsible for the contents and interpretations offered in this paper.
} 


\section{POLITICAL ECONOMY OF ANTIDUMPING AND SAFEGUARDS IN ARGENTINA

\author{
by Julio J. Nogués and Elías Baracat
}

\section{Summary}

Starting in the late 191980s, Argentina implemented a series of reforms that were revolutionary in speed and scope, including trade liberalization. After implementation of these policies, a record number of antidumping (AD) petitions came forward. Under a situation of high inflation, the government reinforced its fiscal and monetary policies by announcing that it would minimize the use of such measures. The flexible disciplines of the existing domestic AD regulations faciliated this objective.

Later, when the GATT/WTO-sanctioned trade remedies were implemented, the government made a serious attempt to establish discipline by including liberal regulations, and creating special institutional arrangements. A presumption built into construction of the new mechanisms was that adhering to WTO requirements would strengthen the resistance against protection. This presumption turned out to be false. Changing circumstances, including severe peso overva luation, had significant impacts on the number and outcome of $\mathrm{AD}$ investigations.

Regarding safeguards, the government followed the letter and the spirit of the WTO agreement. In relation to the number of petitions, few measures have been implemented. Rejections were based on a concern for consumer costs and on failure of the industry seeking protection to provide a convincing modernization plan. This, plus the fact that some cases were brought to the WTO Dispute Settlement Body, have made this a less attractive instrument for protection-seekers than AD.

An important positive side of the story is that unlike previous balance of payments crises, in spite of the major crisis that followed the recent devaluation, the hard-won liberalization has been maintained. 


\section{Introduction}

Statistics from the World Trade Organization (WTO) indicate that after implementing trade liberalization policies in the early 191990s, Argentina initiated a record number of antidumping (AD) investigations. This has triggered criticisms by the media and professional economists as indicating a protectionist bent. Is this interpretation correct? To what extent have $\mathrm{AD}$ and safeguard (SG) measures reversed the trade liberalization policies?

This paper argues that in the drafting of the regulations and in the creation of the institutional mechanism that would administer them, Argentina made a serious attempt to minimize the risks of protectionism. Nevertheless, over time changing domestic and external circumstances, including macroeconomic imbalance and severe peso overvaluation, had significant impacts on the number and outcome of AD investigations. Though the government attempted to use the discretion that existed in the instruments to refrain from protectionist responses, the weight of the investigations under the recently adopted WTO rules was to acknowledge petitioners' "right" to protection rather than to refute it.

The major lessons drawn from the discussion is that the discipline behind use of antidumping and safeguards breaks down when the exchange rate is overvalued; in these circumstances the tools of these instruments such as the injury test, lose their power to discriminate, to limit use. If all suffer serious injury - as will be the case with an overvalued exchange rate, the basic metric of the WTO-sanctioned trade remedies, injury, loses its capacity to distinguish one industry from another and therefore, its capacity to limit application. In this situation, the disciplines inherent in WTO rules, turned out to be more apparent than real.

In order to grasp a better understanding of what effectively happened and draw other lessons, this paper will provide an analysis of the changing circumstances that help to understand the outcome of AD and SG investigations in Argentina. The following is the layout for the remainder of this chapter. Section II briefly describes the extent of trade liberalization measures that were implemented during the late 1980s and early 1990s while Section III presents the changes that were specifically introduced to AD and SG legislation. Section IV offers a description of the nature of the important institutional reform that was implemented in order to administer the injury test on a technical basis. Section V presents an analysis of the outcome of AD investigations while Section VI, does the same with the safeguard cases. Finally, Section VII draws the main lessons.

\section{I.Trade Liberalization and Exchange Rate Policies}

Starting around 1988-89, Argentina undertook a massive program of reform and stabilization, intended to markedly reduce the role of government in the economy liberalize, privatize, deregulate, and open to international competition in goods and capital flows. The adoption of WTO sanctioned trade policy instruments was a significant part though only a part — of this program. Other instruments that Argentina had previously used to manage industry pressures for protection were eliminated, the government's objective was to develop instruments that would provide a means to respond to industry 
pressures for 'exceptions' to the ongoing process of trade liberalization, but at the same time, prove a means to discipline the application of trade restrictions - to ensure that the momentum of reform was maintained rather than reversed as had been the case in previous attempts.

This trade liberalization program was essentially completed during the first half of the 1990s and unlike the previous attempts and in spite of the serious crisis following the devaluation in 2002, it has been sustained. In what follows we summarize what we consider to have been some of the circumstances that shaped the outcome of AD and SG investigations, including the: i) unilateral and Mercosur trade liberalization programs, ii) exchange rate policies, iii) recession and unemployment and, iv) trade performance.

\section{Trade liberalization program}

Starting in the late 1980s, trade liberalization policies resulted in a substantial reduction in average protection. Table II.1 provides information on ad-valorem tariff rates as well as the fraction of tariff lines covered with import licenses. The figures show high and increasing protection until 1987-1988, and relatively fast decline thereafter. In 1989 the dismantling of discretionary import licenses was completed, and average tariff protection declined from $39 \%$ in 1988, to $18 \%$ in 1989. In addition to these unilateral policies, in 1991 Argentina, Brazil, Paraguay and Uruguay signed the Tratado de Asunción that created the Mercosur (Mercado Común del Sur). With some exceptions, the establishment of a common external tariff (CET), and the process of intra-regional trade liberalization were completed in late $1994^{1}$.

Table II.1: Ad-valorem Tariffs and Import Licenses, 1980- 1992

\begin{tabular}{|c|c|c|c|c|}
\hline \multirow{2}{*}{ Year } & \multicolumn{3}{|c|}{ Tariff (\%) } & \multirow{2}{*}{$\begin{array}{c}\text { Import } \\
\text { Licenses }(\%) *\end{array}$} \\
\hline & Maximum & Surcharge & Average & \\
\hline 1980 & 100 & 0 & 25 & 0 \\
\hline 1981 & 75 & 0 & 29 & 0 \\
\hline 1982 & 55 & 0 & 30 & 4 \\
\hline 1983 & 55 & 0 & 30 & 15 \\
\hline 1984 & 55 & 0 & 30 & 51 \\
\hline 1985 & 55 & 10 & 32 & 52 \\
\hline 1986 & 55 & 10 & 39 & 47 \\
\hline 1987 & 50 & 15 & 39 & 51 \\
\hline 1988 & 50 & 15 & 39 & 32 \\
\hline 1989 & 30 & 0 & 18 & 0 \\
\hline 1990 & 24 & 0 & 17 & 0 \\
\hline 1991 & 35 & 0 & 12 & 0 \\
\hline 1992 & 35 & 0 & 12 & 0 \\
\hline
\end{tabular}

* Percent of tariff lines covered

Source: Nogués (2001).

\footnotetext{
${ }^{1}$ Some industries like steel, textiles and footwear benefited from a prolonged period of tariff dismantling that lasted until the end of 1998. Mercosur's CET is escalated (highest rates for manufactures and lowest for fuels), and the average rate during recent years has been around 14\% (ALADI 2002).
} 
Regarding export policies, the most significant changes were introduced to export taxes. Historically, Argentina deepened its isolation by imposing high export taxes on agricultural and agro-based products where it has strong comparative advantage. For example, in the mid 1980s export tax collection represented more than $30 \%$ of total exports. From here on, these tax rates start to decline and by 1992, average collection represented less than $2 \%$ of exports ${ }^{2}$.

\section{Exchange rate policies}

In an attempt to tame inflation, in early 1991 the government introduced by law the Convertibility regime that tied the peso to the dollar at par. After that, capital inflows financed excess demand and together with residual inflation, resulted in a severe overvalued peso. Toward the end of 2001, expectations of devaluation as signaled by the level of country risk increased rapidly and a run against deposits in the banking system accelerated. Eventually in early 2002, the Convertibility regime is abandoned and a major devaluation process unfolded (de la Torre et. al. 2003).

Figure II.1 shows the time-path of the real exchange rate (RER) against the dollar ${ }^{3}$. The numbers indicate an important reduction of the average level during the Convertibility years from 1991until 2002. This overvaluation increased the challenges faced by domestic producers in adjusting to the trade liberalization program. During the second half of the 1990s, the overvaluation was also a factor in slowing growth and pushing the current account deficit to unsustainable levels; in the process, the high level of imports signaled to the AD and SG mechanisms, the continued existence of injury or serious injury to domestic producers.

\section{Figure Il.1: Real Exchange Rate, 1985- 2002}

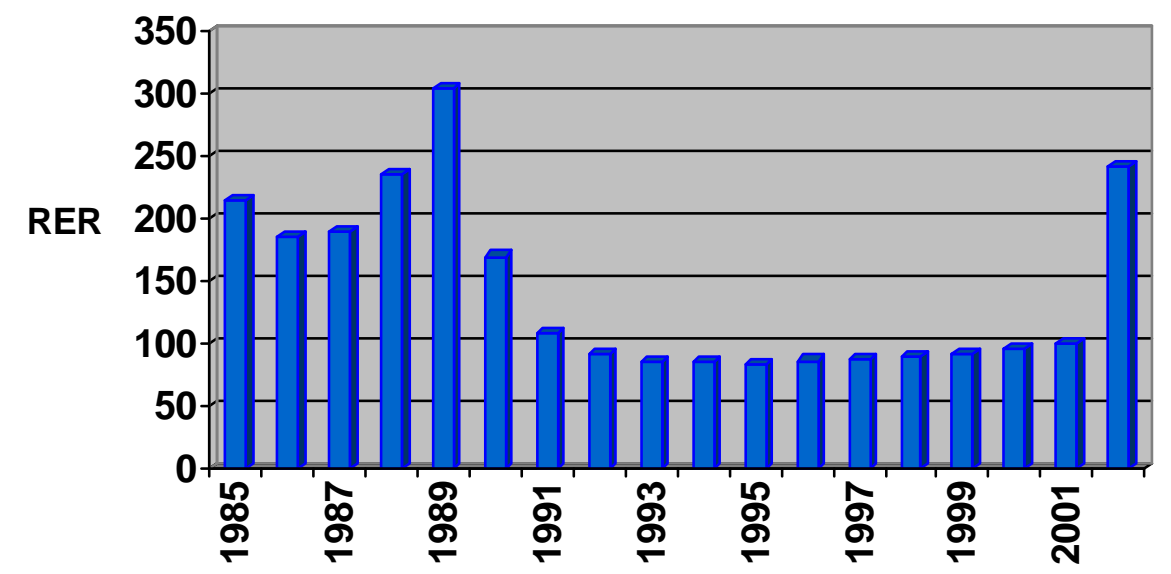

Source: Author's elaboration.

\footnotetext{
2 The policy of essentially no taxes on exports continued until the devaluation of 2002 when they were reimposed. In the early 1990s, financial subsidies granted to non-competitive manufactured exports were also dismantled (Nogués 2001). As discussed in the next section, this dismantling allowed Argentina to sign a subsidy-countervailing agreement with the US with clear gains to domestic exporters.

${ }^{3}$ The RER is estimated as the nominal exchange rate times the ratio of the US to Argentina's cost of living indexes.
} 


\section{Growth, crisis and unemployment}

In addition to these negative circumstances, during the 1990s Argentina was hit by several negative external shocks including: i) the Tequila's effect that started in late 1994, ii) the Asian crisis in 1997, iii) the Russian default in 1998 and, iv) the reduction of international commodity prices in the second half of the 1990s. In spite of these negative circumstances, the economy could generally cope well and continued growing until mid1998 but after that, it entered into a prolonged period of recession that lasted until late $2002^{4}$. This recession was accentuated by Brazil's devaluation of early 1999.

During 2001 and under critical circumstances, a number of measures were attempted in order to reverse what by then was irreversible: a major devaluation. In particular, we note the increase in the ad-valorem tariffs on consumer goods to $35 \%$, the maximum level that Argentina had bounded during the Uruguay Round (UR) negotiations. This increase is indicative of the severe pressures that were being put by imports on the trade regime including as we shall see, on the AD and SG mechanisms. In any case, these measures might have only delayed the severe devaluation that begun to unfold in January 2002 , and during this year, the economy collapsed when GDP declined by $10.9 \%$.

Following the devaluation, three major policy changes were introduced to the trade regime. First, as imports declined rapidly, tariffs on consumption goods were returned to the level of the Mercosur CET. Second, high and escalated export taxes were reintroduced as a measure to finance the government in a situation when the country had defaulted on its external debt. Finally, foreign exchange controls were tightened. We shall see how the devaluation was also accompanied by a reduced demand for AD and SG measures.

Another important aspect of the macroeconomic scenario was the high rates of open unemployment that continue to prevail. In 1993 and for the first time in many years, the unemployment rate surpassed the $10 \%$ level to reach $20 \%$ in 1995 and declined thereafter to around $15 \%$ where it is standing today.

\section{Trade response}

The trade liberalization policies resulted in an important increase in trade flows. Figure II.2 shows that imports increased from less than five billion dollars in the late 1980s and early 1990s, to more than $\$ 20$ billion dollars in 1994-95, and more than $\$ 30$ billion dollars in the late 1990s. During this same period, exports increased from around six billion dollars to more than $\$ 26$ billions in the late 1990s. Not surprisingly, imports from Mercosur grew considerably more rapidly than those from third countries: between 1990 and 2001, aggregate imports grew five times while those from the Mercosur grew by 6.7 times. As indicated later, the relatively fast growth of imports from Brazil, shows in a high demand $\mathrm{AD}$ investigations against this origin.

\footnotetext{
${ }^{4}$ Starting in 1990, Argentina's economy recorded the following growth rates (\%): 1990: $-2.4 ; 1991: 12.7$; 1992: 11.9; 1993: 5.9\%; 1994: 5.8; 1995: -2.9; 1996: 5.5; 1997: 8.1; 1998: 3.9; 1999: -3.4; 2000: -0.5; 2001: 4.4; 2002: -10.9 and, 2003: 8.4.
} 
Figure Il.2: Trade Flows (millions of U\$S)

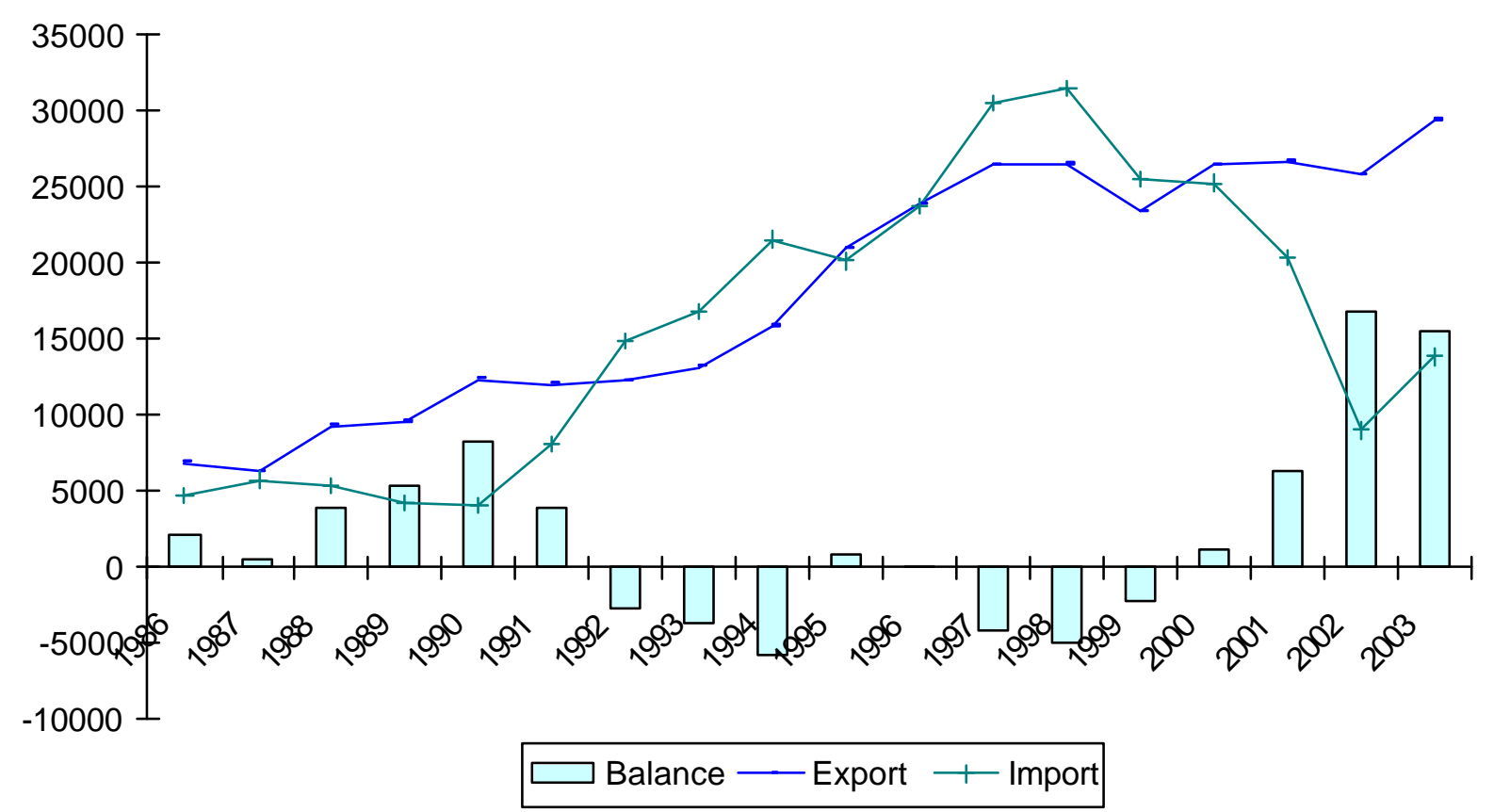

Source: Instituto Nacional de Estadísticas y Censos (INDEC).

\section{Summing-up}

Argentina's trade liberalization policies of the early 1990s were significant and together with other important components of the reform program, played a major role in changing the economic trends of the country. Until 2001-2002 when trade policies were only partially reversed, the economy experienced the longest period with an open trade regime that it has seen in several decades. Nevertheless, the severe overvaluation of the peso, accelerated imports to unsustainable levels and serious injury to domestic producers became a generalized phenomenon that would had obvious impacts on the outcome of AD investigations (Section V).

\section{Reforming Antidumping and Safeguard Legislation}

The economic cabinet that came into power in early 1991, was concerned with the risks that over time, the AD and SG mechanisms along WTO guidelines, would be captured by powerful industries to the detriment of the trade liberalization program ${ }^{5}$. This Cabinet also

\footnotetext{
${ }^{5}$ In a speech delivered in April 2002, Minister Cavallo alerted about the dangers of AD measures when he asserted that: “... behind several antidumping petitions, there are people who would like to return to a closed economy, so that each one of us who live in this country would have to pay higher prices...".
} 
concluded that coming out of a high inflation process ${ }^{6}$, import competition played an important role in the goal to stabilize the price level.

Under this framework, the attention of policymakers was centred in two matters: the content of $\mathrm{AD}$ and SG legislation, and the institutions that would administer the new regulations. In this section we start with a brief discussion of some factors that prompted the demand for "updating" the AD legislation. After that, we discuss the political-economy forces that shaped the contents of the domestic regulations.

\section{External and domestic pressures for reforming legislation}

Under increasing competitive pressures, the liberalization program discussed in the previous section lacked what domestic groups called an "effective" mechanism for providing relief to industries that were injured by imports. Although by the early $1990 \mathrm{~s}$ Argentina had been a GATT Member for several years, it was not a signatory of the Tokyo Codes on AD and countervailing measures (CVM) (GATT 1986). This situation created problems for both, the export and import-competing industries. On the export side, the major problem was in CVM investigations initiated in the United States (US). The reason was that this country's legislation did not apply the injury test to imports from countries that were not signatories to the GATT Code. In this environment, Argentina's subsidized exports faced high risks of being countervailed (Finger and Nogués 1987) ${ }^{7}$. In order to eliminate this source of uncertainty, the government negotiated and in 1991 signed a bilateral agreement according to which the country would dismantle its export subsidies and in exchange, the US would grant the benefits of the injury test ${ }^{8}$.

On the import side, the conclusion by the government was that the existing AD regulations in the Código Aduanero (Law 22,415 of 1981) were excessively protectionist and conflicted with the multilateral disciplines to which the government wanted to move closer as a way putting discipline. For example, according to the Código Aduanero (CA), a margin of dumping above $15 \%$ was sufficient evidence to conclude that the domestic industry was being injured. Domestic producers also complained that the regulations in the CA provided too much discretion and demanded a more "effective" instrument.

Until around the late 1980s, this legislation created no problems because having being a closed economy for several decades, antidumping measures had hardly ever been demanded and therefore, used ${ }^{9}$. This changed when imports began growing rapidly (Figure II.2), and the business community put pressures on the government for implementing import-relief measures.

\footnotetext{
${ }^{6}$ The average annual inflation rates in 1989 and 1990 as measured by the cost of living index had been $3,080 \%$ and $2,314 \%$ respectively.

${ }^{7}$ In fact during the $1980 \mathrm{~s}$, the US countervailed several imports from Argentina including: leather clothing, leather footwear, textile and clothing, steel pipes, petroleum tubes, wool, and several other steel items (Nogués 1991).

${ }^{8}$ Compliance with this agreement resulted in a significant reduction in the number of US countervailing cases against Argentina.

${ }^{9}$ Some AD measures were implemented in the late 70s and early 1980 s when the peso was also highly overvalued. Initially these measures were adopted under Law 21,388 "Régimen de Aplicación de Derechos Antidumping Compensatorios y Móviles" of 1978. Later, this Law was merged in the 1981 CA under which the initial AD cases of the 1990 s were processed.
} 


\section{Political economy of AD and SG legislations}

These shortcomings convinced the government that it had to update its $\mathrm{AD}$ and CVM legislation. The first step was the passage of Law 24,176 in September of 1992 that incorporated the Tokyo Codes, and Decree 2,121 of 1994, that included the operational guidelines. The second step was the creation of the Comisión Nacional de Comercio Exterior $(\mathrm{CNCE})^{10}$ also in 1994, discussed in the next section.

The drafting of operational guidelines to administer the new GATT AD investigations created a debate between the government and a group of powerful importcompeting industries. After passage of Law 24,176 the government hired a prominent Washington-based lawyer who was asked to draft relatively liberal AD regulations (Horlick 1992). In parallel, the Unión Industrial Argentina (UIA) who represents relatively protected manufacturing enterprises, also proposed AD regulations to the government (UIA 1992). Some of the enterprises represented by the UIA had been the target of US investigations and therefore, they were well aware of the highly protectionist nature of this country's AD legislation.

Eventually, Decree 766/94 that created the CNCE and the operating regulations in Decree 2,121/94, indicates that the government favored relatively liberal regulations vis a vis the more protectionist alternative of adopting US-like regulations supported by the UIA. Examples of some of these regulations included:

Lesser duty: Argentina's legislation offers the freedom to apply "lesser duty", or AD measures that are considered sufficient to eliminate injury even if they are lower than the margin of dumping. The principle of "lesser duty" was established by Decree 766/94 as follows: "En el análisis y recomendación de las medidas, la Comisión deberá orientarse con el criterio de contrarrestar el daño y deberá evitar la utilización de la normativa con fines proteccionistas...".

Type of measure: Unlike other countries where AD measures are expressed as an advalorem duty and paid by all imports from the target enterprise / country, Argentina determines a minimum FOB export price below which specific duties are applied to reach the threshold level. Imports carrying FOB prices above the specified level pay no AD duties ${ }^{11}$.

Prospective methodology: Unlike the US where measures are applied retrospectively, a methodology that creates high business uncertainty to exporters (Finger 1993), Argentina applies measures prospectively from the date that the preliminary or final decisions are published.

Duration: Initially, AD measures were usually applied for short periods: two to three years.

Competition authority: Government officials managing antidumping investigations have the right to consult the competition authority to evaluate the likely impact of $\mathrm{AD}$ measures.

National interest: Measures decided by the Minister of Economy can take into account "...la política general de comercio y al interés público" (Article 30 of Decree 1,326/98). This article opens the possibility to deny AD measures in spite of final positive dumping and injury determinations. This clause has been used only once.

\footnotetext{
${ }^{10}$ Discussed in the next section.

${ }^{11}$ Very recently, in some cases, Argentina has begun to establish ad-valorem AD duties.
} 


\section{Safeguards}

Before the passage of Law 24,425 that adopted the UR agreements, Argentina had not issued regulations for safeguards under GATT Article XIX. Again, the fact that the economy had been closed for decades was the main reason explaining the lack of demand for these measures. Another reason was that unlike AD, the country's exports had not been affected by safeguards measures and therefore, neither the business community nor the government was knowledgeable about the effects of this instrument. Even after passage of Law 24,425 in 1994, it took nearly two years before safeguard regulations were issued by Decree 1,059 of September 1996. Therefore, during the crucial years while the economy was adjusting to the trade liberalization program, Argentina operated without a formal safeguard regime. It should also be noted that Mercosur was created without a safeguard instrument and the ban to use these measures, continues today ${ }^{12}$.

\section{Summing-up}

During the early 1990s and in spite of opposition from some interest groups, the government was successful in passing relatively liberal AD legislation. Shortly after Decree $2,121 / 94$ containing the operating regulations had been issued, the Congress approved Law 24,425 that contains "The Results of the Uruguay Round of Trade Negotiations" (WTO 1996). Since then, only one reform to the AD regulations has been implemented through Decree 1,326/98, which included procedural modifications of no substance. As we shall argue in Section V, following pressures from the business community, during 2001 the government drafted regulations that replicated some of the worst characteristics of the US legislation. Nevertheless, the devaluation first, and strong growth in 2003 after, reduced the demand for $\mathrm{AD}$ measures and therefore, the pressures for reforming the $\mathrm{AD}$ regulations and these reforms were never implemented.

\section{Creation of the Comisión Nacional de Comercio Exterior (CNCE)}

Following passage of Law 24,176 that as said adopted the Tokyo Codes, the government began assessing alternative ways of administering the new legislation. The government, convinced of the view that discipline over use of antidumping would have to come from the injury test, looked for a workable way to structure/administer such a test. After surveying experiences in other countries, it concluded that the execution of an injury investigation would have to be entrusted to an independent commission. This section summarizes the history of the process behind this decision.

\section{The role of injury}

At the time, one major piece of evidence in the government's assessment regarding the creation of the CNCE was the conclusion in authors like Finger and Murray (1990) that the: "...patterns of petitions and of results suggests strongly that injury to US

\footnotetext{
${ }^{12}$ This resistance to create a Mercosur safeguard mechanism reflects more the position of Brazil than of the other Members. During the initial years, there were some temporary exemptions to the intra-regional trade liberalization program and some industries also benefited with longer phase-in periods. Nevertheless, these transitional safeguards were mostly ad-hoc.
} 
producers...by import competition is what the antidumping and countervailing law are about...". The findings reported in this and other articles indicated quite clearly that although it is relatively easy to play with the numbers in order to find a positive margin of dumping, the same is not always the case for injury particularly when as in the US, it is evaluated by an independent agency like the International Trade Commission (ITC). For example, these authors concluded that of 100 petitions that end with a formal determination, 56 would not result in a final antidumping or countervailing duty order and, of them, 48 cases by a negative injury determination. This record was a central element in convincing the government of the early 1990s, that an agency that could replicate this performance would add an element of restraint to the administration of AD investigations.

\section{Obstacles to creating an independent agency}

Given that a technical evaluation of injury was the major consideration that prompted the creation of the CNCE, such a decision also implied that Argentina was adopting a two-track mechanism: the margins of subsidy and dumping would be assessed by the Secretariat of Industry and Trade (Secretaría de Industria y Comercio) ${ }^{13}$, while injury would be assessed by the CNCE.

Early in the process, a major obstacle to creating an independent office was made evident. Independence required a law but the Economic Cabinet concluded that submission to Congress had no chances of passage. It also feared that a Congressional debate could undermine and change the relatively liberal regulations that it was proposing to adopt. Therefore, the CNCE was created by Presidential Decree 766/94 with a strong mandate to protect the interests of consumers ${ }^{14}$ : “...with the purpose of ensuring that prices paid by consumers do not exceed those that they would had paid under conditions of normal international competition, maximum levels of efficiency and transparency must be sought in the administration of trade policies against unfair trade".

As said, the main goal behind the creation of the CNCE was that it would undertake injury investigations with high technical standards, and that its decisions would be binding: whenever it reaches a preliminary or final negative determination, the investigation is closed without measures.

\section{Decision-making mechanism}

As is the case with the Secretariat of Industry and Trade, the CNCE functions under the Ministry of Economy (Ministerio de Economía) and its determinations are taken by a majority vote of its President and four Commissioners. Essentially, the process has two steps: (1) an injury report is prepared by the technical staff, and (2) the Board of the CNCE decides whether the evidence supports or not a positive determination ${ }^{15}$. When this type of decision-mechanism was adopted, the thought was that rent-seeking entrepreneurs would approach a Commission with greater care than they would approach one decision-maker more directly subject to political pressures.

\footnotetext{
${ }^{13}$ Over the years, the Secretary of Industry and Trade has changed names several times depending on its changing mandate. At the time of writing this article, its name is: "Secretaría de Industria, Comercio y de la Pequeña y Mediana Empresa".

${ }_{15}$ A Decree can be overturned by another one, while changing a Law requires Congressional debate.

${ }^{15}$ Consensus has not been the common denominator of these votes.
} 


\section{Staffing and budget}

In the creation of the $\mathrm{CNCE}$, achieving technical excellence was an important goal. Except for the President and the Commissioners that are political appointees, the responsibility for its staffing was delegated to a private consulting company specialized in the recruitment of qualified human resources. The comments gathered on this experience indicate that this strategy has had good results ${ }^{16}$. Injury investigations have been done professionally and the record indicates that exporting countries have had no serious objections with the work undertaken by the CNCE.

Nevertheless over the years, successive fiscal adjustments have deteriorated public sector wages with clearly negative implications on employment profiles. As an example, starting in early 2002 and for more than two years, public officials could earn no more than $\$ 3,000$ pesos or around $\$ 1,000$ dollars per month; this applied to the President of Argentina as well as the President of the CNCE and its Commission members. Given this constraint, the public sector lost valuable human ${ }^{17}$.

\section{Summing-up}

Following passage of Law 24,172 that adopted the Tokyo Codes, the government began assessing alternative ways of administering the new legislation. In the end, it determined that an independent agency that would undertake the injury investigations was important to add some degree of economic meaning to antidumping measures. Creation of the CNCE took place approximately at the same time that the country adopted the Uruguay Round agreements. The question of interest therefore is: how successful has it been in disentangling those requests that deserved from those that did not deserve protection?

\section{Determinants of the Petitions and Outcomes of AD Investigations}

The last two sections argued that Argentina approved liberal antidumping legislation and created a technically-oriented institution to manage the injury investigations. Nevertheless, the statistical information indicates that following these reforms, there was a high number of $\mathrm{AD}$ investigations and as we shall see, an increasing share of them ending with positive injury determinations. What went wrong?

This section will argue that while the economy was growing, the $\mathrm{AD}$ mechanism was able to sort out the deserving from the undeserving petitioners. Nevertheless, recession and peso overvaluation increased the share of technical reports by the CNCE indicating that imports were inflicting serious injury to domestic producers.

In order to have a sharper picture of what happened, the analysis in this section will discuss the following topics: 1) impact of political determination and economic cycles on the demand for $\mathrm{AD}, 2$ ) country incidence and coverage of $\mathrm{AD}$ measures, 3) overvaluation and the incidence of injury determinations, 4) dumping determinations and $\mathrm{AD}$ measures

\footnotetext{
${ }^{16}$ Commissioners can only be removed by the Executive Power. Also, Members of the Board and the staff are required to follow behavioral procedures and in fact, Decree 766/94 stipulates that failure to comply with this requirement can trigger removal of the staff violating it.

${ }^{17}$ As will be indicated in Section V, unlike the CNCE, budget constraints have weaken the capacity of the Undersecretary of Gestión ComercialExterna (UGE) to complete accurate dumping investigations. For example, the UGE has lacked resources to undertake in-situ verifications of prices.
} 
and, 5) mounting pressures to replicate a US-like antidumping mechanism. The section ends with brief summary that attempts to unify the story that emerges.

\section{Impact of political determination and economic cycles}

Between the late 1980s when trade liberalization measures started to be implemented and 1994, Argentina administered AD measures under the guidelines of the Código Aduanero (CA). According to the 1994 and 1995 annual reports of the CNCE (www.mecon.gov.ar/cnce/informes_anuales.htm), during these years the government received $135 \mathrm{AD}$ petitions of which 69 investigations were initiated, and measures were applied in 19 cases. These numbers indicate that trade liberalization was accompanied by an important increase in the demand for $\mathrm{AD}$ protection but the political determination of the government remained in favor of openness ${ }^{18}$.

As said, the strategy of the government during the initial years of the trade liberalization program was to delay decisions on $\mathrm{AD}$ investigations while the new regulatory and institutional architectures described in Sections III and IV were being completed. Because under the regulations of the CA used to process the early petitions, there were no time limits for the different steps of AD investigations including opening one, the government retained important degrees of discretion. Former Minister Cavallo often reiterated that the government would be very careful in the use of $\mathrm{AD}$ measures until the price level had been stabilized. Recall that during those days, the taming of inflation was a major policy objective and the Government considered that import-competition had an important role to play in attaining it.

Furthermore, during the early years of operation of the CNCE, the relatively high incidence of negative determinations indicated below, is likely to have reduced the number of "frivolous" petitions. Political determination in favor of openness and a technicallyoriented CNCE defined an environment where ex-ante, an $\mathrm{AD}$ petition had a high likelihood of ending in a negative determination. Another factor reducing the demand for $\mathrm{AD}$ protection was the time and money a petitioner would have to expend to present and defend an investigation with a low likelihood of providing positive returns ${ }^{19}$.

In January of 1995, the CNCE began operating and between 1995 and early 2004, it completed 111 investigations, or 166 when each origin is considered as a different case ${ }^{20}$. In this relatively brief experience, a first point to note is the cyclical behavior of the number of new investigations: recessions were accompanied by increasing number of initiations while during growth years, this number declined. Figure V.1 shows that a relatively high number of 25 investigations were initiated during the crisis year of 1995 (Tequila effect), but when the economy regained strong growth until mid-1998, initiations declined drastically and reached only four cases in this year. After that, four consecutive years of negative growth, increased initiations to an average of 25 per year i.e. $79 \%$ higher than the

\footnotetext{
${ }^{18}$ Nevertheless after 1998, 22 additional cases of the 69 that were opened between 1988 and 1994 ended with measures.

${ }^{19}$ By some accounts of key informants, perhaps as much as $50 \%$ of potential petitions, in the end decided against submission. Regarding cost, by the estimate of one informed observer, during the years of Convertibility the processing of an antidumping investigation could cost firms around \$60,000 dollars in legal fees. This sum was and still is well beyond the means of small and several medium sized enterprises.

${ }^{20}$ Annex 2 presents a description of the administrative procedures followed by AD investigations.
} 
average number during the growth years from 1996 to $1998^{21}$. Finally, after the devaluation in early 2002 and strong growth in 2003, the number of initiations declines to 14 in 2002, and only 4 in 2003.

Figure V.1: AD Initiations and GDP Growth (\%): 19952003

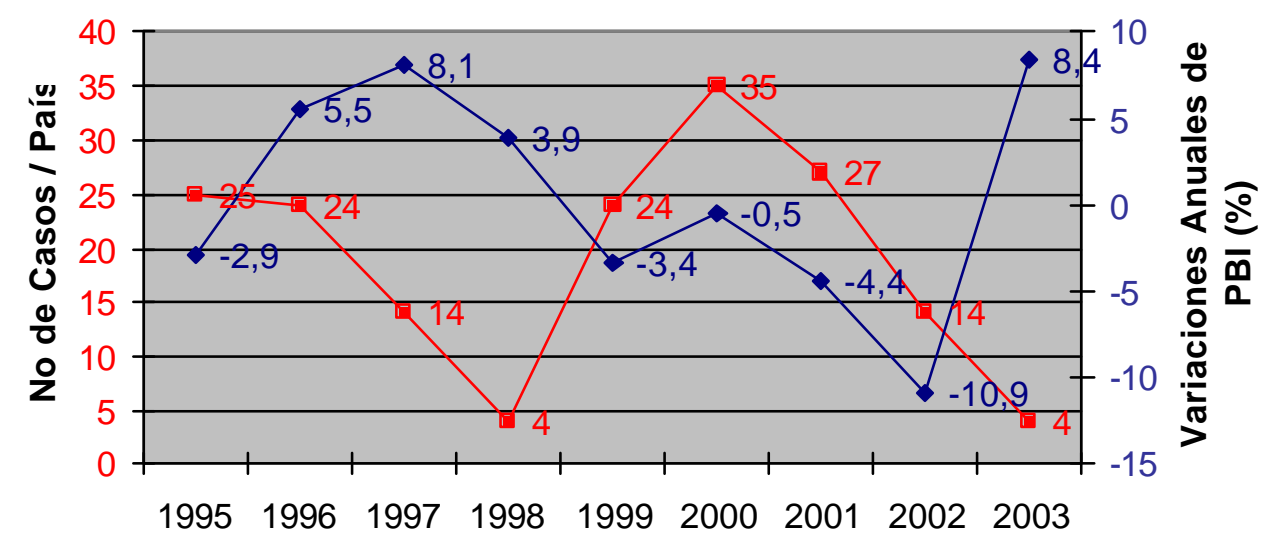

Source: Author's elaboration with data from the CNCE and INDEC (Instituto Nacional de Estadísticas y Censos).

\section{Winners and losers of the AD mechanism}

Table V.1 presents the incidence of AD investigations by requesting industries. As seen, $1 / 3$ of all the cases have been demanded by producers of steel and steel products, and another $13 \%$ by chemical industries. Except for electrical equipment, the incidence of AD investigations in favor of other industries has been much lower. As discussed in Section III, one hypothesis explaining the high incidence of $\mathrm{AD}$ cases requested by steel producers is that during the 1980s this industry had been hit by several investigations particularly in the US (Nogués 1991). As a consequence, it was more under alert of how AD can be used for obtaining import-relief than other industries ${ }^{22}$.

\footnotetext{
${ }^{21}$ Other factors that pushed the number of investigations during the recession years were revisions of earlier cases where measures had normally been imposed for two years, and the end of the phase-in period of Mercosur in early 1999 where as said, safeguards are not allowed.

22 This is only part of the story. As seen in Annex 1, the high incidence of the steel cases is accounted not only by what is known as "big steel" like cold-rolled and hot-rolled laminated products but also, by several smaller industries such as locks, bathroom faucets, etc. that had not been under AD attacks in the earlier years.
} 
Table V.1

Antidumping Investigations by Requesting Industries

1995-2004

\begin{tabular}{|lcc|}
\hline & $\begin{array}{c}\text { Number of } \\
\text { Investigations }\end{array}$ & $\begin{array}{c}\text { Percent } \\
\text { Positive Injury } \\
\text { Determinations* }\end{array}$ \\
Steel \& Steel Products & 36 & 94.4 \\
Chemicals & 14 & 42.9 \\
Textiles \& Textile Products & 5 & 100.0 \\
Plastic \& Plastic Products & 6 & 83.3 \\
Electrical Equipment & 9 & 55.6 \\
Processed Food & 6 & 33.3 \\
Machinery \& Non-Electrical & 4 & 75.0 \\
Equipment & 4 & 75.0 \\
Wood \& Paper Products & 3 & 33.3 \\
Rubber \& Rubber Products & 11 & 100.0 \\
Consumer Durables & 13 & 76.9 \\
Others & 111 & 76.6 \\
Total & & \\
\hline
\end{tabular}

* When the final determination is negative in some parts and positive in others, we have assumed a positive finding. If we had assumed that the six mix cases in Annex 1 were negative, then the percent of positive determinations would had declined from $77 \%$ to $70 \%$.

Note: Negative preliminary injury determinations are taken as negative cases and undertakings as positive determinations. Annex 1 indicates that of the 26 negative cases, 10 were decided at the preliminary stage; 15 at the final stage, and one on the basis of the national interest.

Source: Author's elaboration based on Annex 1 .

The last column of the table presents the percent of cases with a positive injury finding. It is of interest to note that while $94 \%$ of the steel cases ended with a positive determination, only $50 \%$ of the chemical cases did so. As seen, $77 \%$ of all investigations ended with a positive injury determination, a figure that is higher than what has been estimated for other countries including the US (Irwin 2002), and Mexico (Francois and Niels 2003).

Table V.2: Argentina's AD investigations by target country; 1995-2004*

\begin{tabular}{|c|c|c|}
\hline Brazil & 31 & \\
\hline China & 34 & \\
\hline United States & 9 & \\
\hline European Union* & 42 & \\
\hline Others & 50 & \\
\hline Total cases/country & 166 & \\
\hline
\end{tabular}

Source: Author's elaboration based on Annex 1. 
Table V.2 shows that at the country level, China and Brazil have been the hardest hit by Argentina's AD investigations. The high incidence of cases against Brazil can be explained by the regional liberalization in Mercosur and the absence of a safeguard mechanism for fine-tuning intra-regional trade flows. This implies that import relief measures can only be provided by AD measures or some other obscure non-tariff barrier ${ }^{23}$.

Table V.3 presents two indicators of the importance of AD: the value of imports covered as a share of total imports, and the value of apparent consumption affected as a share of manufactured value added ${ }^{24}$. As in other studies, the first indicator shows relatively low values but this is not surprising given that the objective of $\mathrm{AD}$ measures is precisely to reduce imports. Still, the rapidly increasing trend since 1995 is evidence of an AD system that is moving closer to the needs of petitioners.

The second indicator captures better the economic importance of AD protection on the domestic economy. It shows the value of apparent consumption covered by AD investigations and $\mathrm{AD}$ measures (published by the $\mathrm{CNCE}$ ), as a share of value added by the manufacturing sector (published by the Instituto Nacional de Estadísticas y Censos, INDEC). This indicator also shows an increasing trend from less than $1 \%$ to around $6 \%$, where it was standing in 2003.

Table V.3

Coverage of AD Measures (\%)

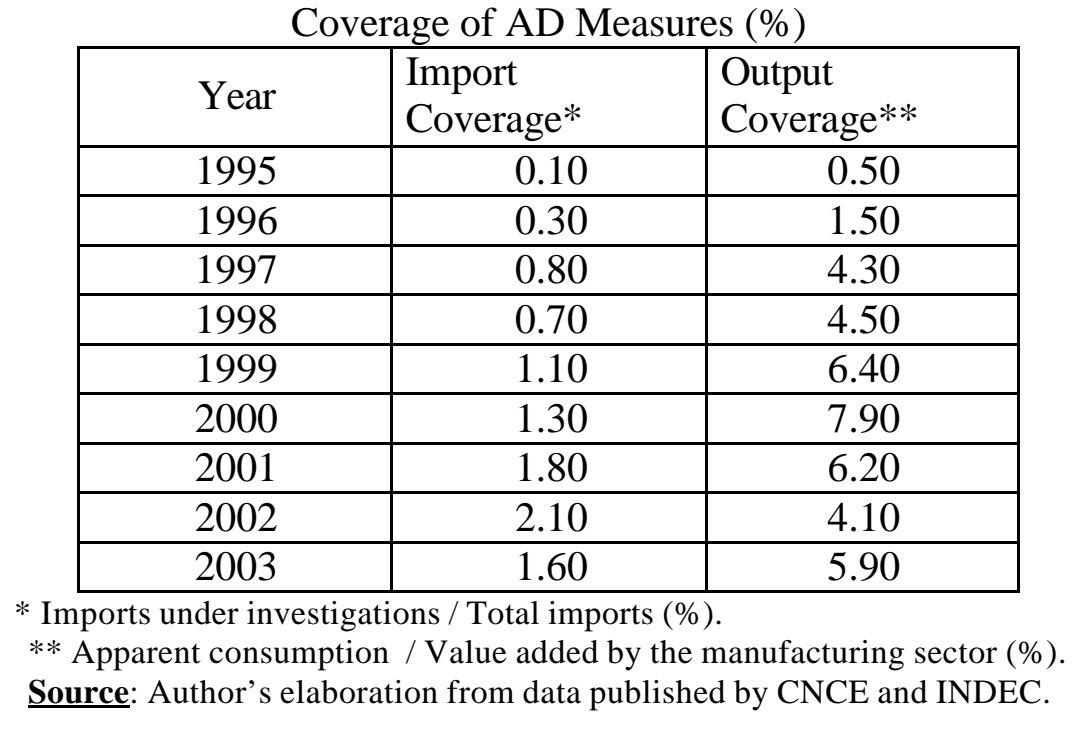

\section{Overvaluation, recession and the incidence of injury determinations}

From what we know, the CNCE has met the goals that its original designers had; its injury analysis have been driven by objective economic factors and there are no precedents indicating that foreign exporters have had serious objections to its work. Therefore, we take its findings as a good approximation of the extent of injury suffered by the domestic economy.

\footnotetext{
23 According to the annual reports of the CNCE, during 1995-2003, the share of Brazil in imports covered with $\mathrm{AD}$ measures is $40 \%$, while the share of this country in the number of AD investigations is $19 \%$ (TableV.2).

${ }^{24}$ In both cases, imports affected include the sum of the value of imports under AD measures and under investigations. Imports under investigation are included because market conditions are likely to be affected since the very moment that an AD investigation is requested (see for example Prusa 1992). An earlier estimate of the import coverage indicator is presented in Sanguinetti and Salustro (1999).
} 
The analysis presented in Section II and the time trends of initiations (Figure V.1) suggest several hypotheses. First, currency overvaluation-cum recession increased the likelihood of injury which should show in increasing shares of positive determinations. Second, the peso devaluation in early 2002 and strong growth in 2003, should have relaxed the demand for antidumping and safeguard measures. Finally, given the important efforts that were put in designing liberal regulations and creating technically-oriented institutions, a relatively high number of negative injury determinations should have characterized the functioning of Argentina's AD mechanism. The statistical analysis that follows will test these hypotheses.

Table V.4 shows the outcome of the injury investigations between 1995 and 2003. The evidence indicates that between 1995 and 1998 when the economy was growing strongly, the share of negative injury determinations by the CNCE was relatively high but during the following years, this share declined. Our hypothesis is that the continued overvaluation of the peso, and the prolonged recession between late 1998 and 2002, increased the likelihood that technical reports prepared under the WTO AD guidelines, would show in an increasing share of positive injury determinations. Second, regarding the effects of the 2002 devaluation and 2003 growth, the figures indicate that although these factors reduced the number of petitions and initiations (Figure V.1), they had no impact

Table V.4

Injury Determinations in AD Investigations: 1995- 2004

\begin{tabular}{|c|c|c|c|}
\hline \multirow[t]{2}{*}{ Years } & Determination* & Preliminary & Final** \\
\hline & $\begin{array}{l}\text { Positive } \\
\end{array}$ & 18 & 21 \\
\hline \multirow[t]{3}{*}{$1995-1998$} & Negative & 7 & 14 \\
\hline & $\%$ Negative & 28.0 & 40.0 \\
\hline & Positive & 45 & 64 \\
\hline \multirow[t]{3}{*}{$1999-2004$} & Negative & 2 & 3 \\
\hline & $\%$ Negative & 4.5 & 4.5 \\
\hline & Positive & 2.0 & 31 \\
\hline \multirow[t]{3}{*}{ 1999-2001 } & Negative & 2 & 1 \\
\hline & $\%$ Negative & 10.0 & 3.2 \\
\hline & Positive & 25 & 33 \\
\hline \multirow[t]{3}{*}{ 2002-2003 } & Negative & 0 & 2 \\
\hline & $\%$ Negative & 0 & 6.1 \\
\hline & Positive & 63 & 85 \\
\hline \multirow[t]{2}{*}{ 1995-2004 } & Negative & 9 & 17 \\
\hline & $\%$ Negative & 12.5 & 16.7 \\
\hline
\end{tabular}

* Cases included in each period are determined according to the year when the final determination was published.

** The case decided on national interest (Decree 69/ of 2001), is taken as a final negative determination.

Note 1: Undertakings are assumed to be final positive determinations; Annex 1 shows that there were two undertakings during 1995-1998, and four during 1995-2004.

Note 2: In investigations arriving at mixed results, I have assumed that the determination is positive.

Note 3: Revisions are counted as individual cases.

Source: Author's elaboration based on information presented Annex 1. 
on negative injury determinations ${ }^{25}$. One hypothesis is that the investigations that were concluded during this period, were still affected from injury attributed to imports in previous years. Finally, the incidence of negative injury determinations under the CNCE has not been higher than that observed in other countries with independent commissions like the US (Irwin 2002), or with centralized systems like Mexico (Francois and Niels 2003).

In one important sense, the new investigations under WTO regulations differed from the previous regulations in the Código Aduanero: degree of discretion. The new regulations took away much of the discretion that was in the old system, including the discretion of if and when to open an investigation. Recall that under the system that prevailed until 1994, the government received 135 AD petitions of which only 69 were investigated. These numbers show that at least in part, it was the exploitation of the discretion in the old system that kept relatively low the number of investigations ${ }^{26}$; strong growth during the early 1990s, and political determination in favour of openness were the other important factors ${ }^{27}$.

\section{Dumping determinations and AD measures}

In most cases, the Undersecretary of Gestión Comercial Externa (UGE), has arrived at positive determinations on dumping and therefore, this stage of the investigation has generally not worked as a filter of AD petitions. It should be said that the UGE lacks resources to verify in-situ, the prices offered by exporters. This has been a problem in some decisions on dumping margins particularly, after a 2001 WTO ruling against Argentina in a ceramics tile case ${ }^{28}$. In any event, according to key informants, this ruling has made the UGE more careful in the use of information on prices provided by both, the petitioners and the exporters.

\footnotetext{
${ }^{25}$ The evidence in Annex 1 indicates that some of the industries receiving AD protection during recent years include: tires, flat steel and iron products ("big steel"), laminated steel ("big steel"), chemical products, faucets, air conditioning equipment, etc.

${ }^{26}$ Nevertheless, it is relevant to note that the CNCE retained authority to administer Article 5.3 of the Antidumping Agreement on initiations stating that: "The authorities shall examine the accuracy and adequacy of the evidence provided in the application to determine whether there is sufficient evidence to justify the initiation of an investigation". Key informants have indicated that until around 1998, an important share of petitions did not pass the standards set by the CNCE to administer this article.

${ }_{27}$ As discussed in the next section, until the late 1990s when WTO rulings against Argentina were published, the textiles and footwear industries received safeguard protection. These measures also lessened the demand for $\mathrm{AD}$ protection.

${ }^{28}$ In the case: "ARGENTINA - MEDIDAS ANTIDUMPING DEFINITIVAS APLICADAS A LAS IMPORTACIONES DE BALDOSAS DE CERÁMICA PARA EL SUELO PROCEDENTES DE ITALIA”, Italy explained that some Italian firms had presented price information under confidentiality together with non-confidential summaries so that the UGE could determine dumping margins at the firm level. Italy argued that when the UGE decided not to utilize the information provided in these summaries, Argentina violated Article 6 of the Antidumping Agreement. The Panel concluded that: "Argentina actuó de manera incompatible con el párrafo 8 del artículo 6 y con el Anexo II del Acuerdo Antidumping al descartar en gran parte la información presentada por los exportadores para la determinación del valor normal y del precio de exportación, sin informar a los exportadores de las razones del rechazo" (www.docsonline.wto.org/gen home.asp?language=1\& =1 ). Note that lacking resources to verify information can put a government in a bind: if it rejects the information supplied by the petitioner, it is in political trouble at home, perhaps caught up in judicial appeal. If it rejects the information supplied by the exporter, it in trouble in the WTO. We owe this comment to Mike Finger.
} 
Regarding the stringency of $\mathrm{AD}$ barriers, this is a tricky issue to assess. The reason is that imports can be redirected from a country against which measures have been imposed, towards other origins. Therefore, an AD duty can be very high but if the source of imports can be substituted, then the protectionist impact may not be that serious. On the other hand, $\mathrm{AD}$ duties can be relatively low but if barriers are imposed against all of the major suppliers, then these measures are likely to be unavoidably costly ${ }^{29}$.

Keeping this in mind, in what follows we offer brief comments on some characteristics of Argentina's AD measures. First in regard to the methodology used to assess the margin of dumping, the information presented in Annex 1 shows that in the great majority of cases, the investigations have estimated normal values from domestic market prices $^{30}$. The most significant exception has been cases against China where normal values have been estimated from domestic prices in surrogate market economies. It is also of interest to note that normal values from cost-based estimates have been used in only one case: laminated steel products imported from Kazakhstan and Rumania (Annex 1).

A second issue of interest to note is that the duration of $\mathrm{AD}$ measures have been increasing. During the initial years until around 1998, this duration was relatively short: usually two to three years. Nevertheless more recently, the normal duration has been extended and now it is not uncommon to find measures being imposed for five years (http://www.mecon.gov.ar/cnce/Archivos/cuadros/m_vigentes.pdf).

A third topic refers to the nature of the $\mathrm{AD}$ measure. We mentioned before that during the initial years of operation of the system, the usual measure was the determination of a reference FOB export price; when the price of imports is lower than this reference, a specific duty would close the gap. On the other hand, imports with invoice prices above the regulated FOB price, paid no duties. More recently however, the system has moved closer to one where the dumping margin is transformed to an equivalent ad-valorem duty that is paid by all imports from the target country/enterprise i.e. closer to the US system.

On lesser duty, the analysis presented above indicated that this was a characteristic of the liberal approach that prevailed when Argentina's AD mechanism was designed during the early 1990s. Regarding the extent to which lesser duties have been applied, it is of interest to note that contrary to our expectations, the information presented in Table V.5 indicates that during the initial years of operation of the AD mechanism, in relatively few cases was the concept of lesser duty applied: three out of 16 determinations. This contrast with 22 cases out of 78 determinations after 1998 when most of the time, the economy was in recession. This indicates how the degrees of freedom allowed by WTO rules can be used to lessen protectionist impacts of $\mathrm{AD}$ measures even in situations of severe recession.

Finally Table V.5 presents estimates of the average maximum margins of dumping in ad-valorem equivalents. Because Argentina has usually determined minimum FOB export prices below which specific AD duties are applied, the rates in Annex 1 correspond to maximum values; when export prices are above the minimum, no specific $\mathrm{AD}$ duties are

\footnotetext{
${ }^{29}$ In general, we believe that competitive imports have remained free of AD duties and therefore, importers have been able to substitute country of origin obviously at a cost. However, in cases like "big steel" ones, information indicates that a chain of successive investigations have affected imports of hot and cold rolled laminated plates from most origins (Annex 1). In most instances, AD investigations of these imports have been opened in response to protectionist measures (safeguards and AD barriers) from industrial countries that have depressed world steel prices.

${ }^{30}$ The source of information on prices has usually been: journals, data gathered by commercial attaches, or directly provided by the exporters.
} 
applied (Section III). This as well as the fact that Argentina has often applied lesser duties, implies that the numbers in Table V.5 can be well above the AD duties actually applied. Therefore, we take these numbers more as an indication of dumping margins than of the stringency of AD measures. With this in mind, we first note that the estimates for the 19952004 period, show dumping margins that are unusually high. Second and more surprising to us, is that the breakdown of this period in the high growth and low growth years reveals that high dumping margins has been a persistent characteristic and not one that has been particularly acute in bad times 31 .

Summing up, Argentina has not resorted to what is generally considered to be the most subjective and protectionist methodology for estimating normal values namely, costbased estimates. It is also important to note that in more than $20 \%$ of the observations presented in Annex 1, the AD measure has been a lesser duty, and this was the case even during the recessionary years between 1999 and 2002; the WTO rules indicated injury but still the government applied some of the liberal dimensions of its legislation.

Table V.5: Antidumping Measures

\begin{tabular}{|c|c|c|c|}
\hline Measure & $\mathbf{1 9 9 5 - 1 9 9 8}$ & $\mathbf{1 9 9 9 - 2 0 0 3}$ & $\mathbf{1 9 9 5 - 2 0 0 3}$ \\
\hline & & & \\
Duty criteria, number of cases: & 16 & 78 & 94 \\
- Full Dumping & 13 & 56 & 69 \\
- Lesser Duty & 3 & 22 & 25 \\
\hline Average dumping margin (\%) & 315 & 251 & 267 \\
\hline
\end{tabular}

Notes: The end-points of the different periods are defined by the dates when the final measures were announced.

Under the duty criteria column of Annex 1, the figures are calculated from the number of countries under investigations and not from the number of cases.

For several cases, we lack information on dumping margins.

Source: Based on Annex 1.

Another example was the application of the national interest clause in one case decided in $2003^{32}$. Nevertheless, it would be an error to conclude from here that Argentina's AD mechanism is relatively lenient. The fact of the matter is that after its initial years, the system has evolved towards one that has provided higher levels of protection through inter alia, extending the duration of the measures and changing the nature of the AD barrier. But

\footnotetext{
${ }^{31}$ In order to complete the picture, we have estimated on the basis of information in Annex 1, that the average minimum margin of dumping is $109 \%$. Again for the reasons explained in the text, this number is not an indication of the height of AD duties. In addition to the factors mentioned there, we have been informed that there have been some cases / enterprises that have been found by the UGE not to be dumping.

${ }^{32}$ Imports of glifosato from China. This product is an herbicide developed by Monsanto which in combination with genetically modified seeds, accounts for an important share of increasing agricultural productivity observed in recent years. Here, the final dumping and injury determinations were positive but the case was closed without AD measures. The politicaleconomy of this decision had to do with two important factors. First, China has become a major importer of several agricultural products from Argentina, specially soybean which uses glifosato. The second factor has to do with a forceful domestic agricultural lobby indicating that a wrong would be done if $\mathrm{AD}$ measures would had been implemented against these imports.
} 
the most important factor indicating a protectionist trend, increasing share of positive injury determinations, was not the effect of an administration that changed its objectives, but mainly of the application of multilateral rules that under Argentina's economic situation, clearly signaled the existence of injury.

\section{Overvaluation and pressures for shifting to a US-like AD legislation}

A proposal for reforming AD regulations is contained in Decree 1,088 of 2001. The protracted recession that had started in late 1998, and the important overvaluation discussed in Section II, was major factors pushing entrepreneurs to seek a more protectionist legislation. The pressures were also exacerbated by the highly publicized and politicized US AD and CVD measures against honey imports from Argentina ${ }^{33}$. This investigation had ramifications over many honey producing provinces, and over thousands of beekeepers both of whom faced serious problems in meeting the information requirements and deadlines established by the US Department of Commerce (Nogués 2003) ${ }^{34}$. Decree 1,088 was drafted in this atmosphere of recession, currency overvaluation and animosity. Under these unfavorable circumstances, the same Minister of Economy that had signed Decrees 766 (creation of CNCE), and 2,121 (liberal AD regulations) in 1994, concluded in 2001 that it made little sense to continue implementing $\mathrm{AD}$ regulations that provided foreigners and in particular the US, more lenient treatment than what Argentina's exporters were receiving abroad. The natural reaction was to adopt US-like regulations - included in Decree 1,088 -, such as: (i) shorter time periods of the different stages of AD and CVD investigations, particularly in the opening stage and, (ii) the adoption of retroactive provisional measures and retrospective final $\mathrm{AD}$ and $\mathrm{CV}$ duties ${ }^{35}$.

In spite of the fact that Artic le 71 of Decree 1,088/01 stated that it would become legally binding on January 1, 2002, it never did. In late December 2001 and amidst a major economic and social crisis, the President of Argentina resigns and in early 2002, a new one is sworn in. As shown in Figure II.1, by then the devaluation process had been set in motion, and the RER had started its path of accelerated climbing. Later in 2003, strong growth resumed. Under these conditions, the pressures for reform lessened, and the new economic team concluded that the time for implementing the changes of Decree 1,088 had not arrived. Now the expectation is that most likely, this Decree will never be implemented $^{36}$.

\section{Summing-up}

During the early years of the reform program when the country had not yet signed the Tokyo Codes, what was not in the books (things like no time limits for deciding on the opening of investigations, political determination against accepting protectionist demands,

\footnotetext{
${ }^{33}$ AD measures were also requested against imports from China. At the peak of the tensions, an important number of beekeepers gathered at Plaza de Mayo to demonstrate against the US investigation.

${ }^{34}$ A request by the Minister of Economy to the US Secretary of Commerce to soften the AD measures, had a negative response on the basis that these are decisions taken at technical and not political level (Nogués 2003).

${ }^{35}$ On retroactive measures, it is of interest to quote the then Secretary of Foreign Trade in a newspaper article commenting the reforms: "through the retroactive application of measures, industry is assured that protection against unfair trade is provided since the date that the investigation is opened.." (Giorgi 2001).

${ }^{36}$ One hypothesis is that the existing regulations have proved to be capable of supplying the protection that is demanded by the least competitive industries.
} 
processing costs, and high likelihood of negative injury determinations), were of great importance for distilling "frivolous" petitions for AD measures.

When in late 1994, the government put into effect the new WTO AD regulations, it lost much of the discretion that it had in the previous legislation; for example, it could no longer decide or delay the initiation of investigations with as much freedom as it used to have. As a consequence, since around 1995 but particularly after 1998, most of the petitions for $\mathrm{AD}$ measures have ended in formal investigations.

Having opted for the adoption of multilateral rules, the government searched for ways of preventing that the AD and SG mechanisms would be co-opted by special interests. Towards this end, it passed liberal AD legislation and created the CNCE that would administer injury reports in $\mathrm{AD}$, countervailing, and safeguard investigations. The government believed that managing injury investigations on a technical basis - within the regulations established by WTO - was the key to maintaining discipline over use.

At the technical level, Argentina's experience with conducting injury tests was a success and the CNCE did a professional job. On the dumping side, the ceramics tiles case points to the lack of resources available for measuring dumping margins more than to a lack of professionalism. Argentina's management of pressures for protection on a technical basis was however less successful. The delicate macroeconomic problems exceeded the capacity of the instrument to distinguish likely deserving from undeserving petitions; in the situation that existed, dumping and injury reports tended more often to document the "right" of the petitioner to protection than to refute it. Pressures on the AD mechanism were heightened by the Mercosur where safeguards are banned; relief from imports coming from Brazil has been provided essentially through AD measures. Under these conditions, the technical standard tended to support restriction and increasingly, the AD mechanism became a reliable instrument for petitioners. It is nevertheless of interest to note that in several instances, even during the recession years, the government resorted to the liberal aspects of the legislation, such as the implementation of lesser duties, in order to graduate the protectionist effects of AD measures.

Over the 1995-2004 experience, the evidence indicates that in terms of the share of negative determinations, Argentina's AD mechanism has not delivered less protection than those in other countries that are either administered with independent commissions like the US, or centralized AD mechanisms like Mexico. Nevertheless, the experience of Argentina is successful across a significant dimension: in spite of the weight of negative circumstances, there has been a resolve of successive governments to hold the line against import restrictions. Also, today there are far fewer and more transparent trade restrictions in place than had been the experience in previous restructurings of the exchange rate when trade liberalization measures were fully reverted by resorting to higher tariffs and several obscure and arbitrary instruments (Nogués 1986).

Finally, a visible attempt at eroding the mechanism only came in 2001 after more than three consecutive years of recession and currency overvaluation. The tensions under these circumstances were heightened by the honey case that illustrated how other WTO members like the US, used the capacity of the multilateral rules to provide more effective AD protection than Argentina did. Nevertheless, following the 2002 devaluation and 2003 growth experience, demands for more protectionist regulations and AD measures have lessened significantly and apparently, neither the government nor the private sectors continue to push for the adoption of US-like regulations. We take this as another indication of a determination to hold the line. 


\section{Safeguards}

Regarding the use of safeguards for fine-tuning the trade liberalization program, the experience of Argentina can be summarized as quite unsuccessful. Before the UR agreements came into effect, the country could restrict imports at ease and no safeguard regulations were necessary. This explains why during the initial years of the trade liberalization program, the government increased barriers at the border in order to facilitate adjustment of some indus tries like footwear, textiles and clothing. This freedom to finetune the liberalization program came to an end when the UR agreements began to be enforced in 1995, and successive adverse WTO Panel Reports reduced the margins for using safeguard measures.

For these industries, the safeguard instrument that was used was the so-called minimum specific import tariffs or, "derechos de importación específicos mínimos" (DIEM's) ${ }^{37}$. The equivalent ad-valorem tariffs of the DIEM's was often above $35 \%$ so when the UR came into effect in 1995, trading partners requested Argentina to reduce them in line with the "maximum tariff" that the country had binded in these negotiations. After consultations ended with negative results, trading partners initiated a case in the Dispute Settlement Body of the WTO ${ }^{38}$.

In what follows we comment on the experience with safeguards under GATT Article XIX and the Safeguard Agreement, as well as with the textile safeguards under the WTO Agreement on Textiles and Clothing (ATC).

\section{Safeguards under GATT Article XIX and the SA}

Table V.6 shows that there have been 13 petitions under the Safeguard Agreement of which: i) seven were turned down by the CNCE before initiation, ii) one was withdrawn by the petitioner, iii) one was returned to the petitioner on the basis of insufficient information and, iv) four resulted in the opening of investigations; safeguard measures were introduced in three of them: footwear, canned peaches and small motorcycles. In the fourth case, the toy industry, the CNCE determined at the end of the investigation that safeguards were not applicable.

We have undertaken interviews in order to understand why so few safeguards were processed by the CNCE. Some of the factors mentioned include: (i) the injury test in safeguard cases is more demanding than in AD cases, (ii) the domestic industry has to be able to show that it can overcome its competitive disadvantages by implementing a plan of structural reforms (in the cases of toys, cardboard and bicycle tires, for instance, the evidence was not strong enough to argue that these requirements could be met), (iii) in

\footnotetext{
${ }^{37}$ The DIEM's are minimum specific duties defined for the target products. These duties are applied whenever they are higher than the collections from the ad-valorem tariffs. The regulations established that the DIEM would not be charged whenever it was lower than the duties collected through ad-valorem tariffs. It is also of interest to note that the resolutions that implemented the DIEM's acknowledged the plans and actions by the protected industries to invest and reconvert. Therefore the objective behind these barriers, were similar to those sought by safeguard measures without being called in this way.

${ }^{38}$ Consultations requested by the US in 1996 led to the formation of the Special Group: "Argentina Medidas que afectan a las importaciones de calzado, textiles, prendas de vestir y otros artículos". This group established the incompatibility of several DIEM's and finally, the Apellate Body issued its decision on March of 1998. A similar request against Argentina was also presented by the European Union (EU).
} 
some cases, the domestic industry accounted for only a small fraction of the market with most of the apparent consumption being supplied by imports (in toys for instance, this was a factor included in the assessment of the CNCE), (iv) the fact that safeguards are closely watched by the WTO implies that a careful evaluation of possible demands for trade compensation has to be undertaken; when an industry like camping gear is considered to be able to reconvert without safeguards, the CNCE turned down the petition and finally, (v) the WTO dispute in one of the first safeguard cases processed by the CNCE (footwear), raised fears that other cases could follow.

Table V.6

Outcome Safeguard Petitions

\begin{tabular}{|l|l|l|}
\hline $\begin{array}{c}\text { Year of } \\
\text { Petition }\end{array}$ & \multicolumn{1}{|c|}{ Product } & Notes \\
\hline 1996 & Footwear & Positive injury determination \\
\hline 1997 & Toys & No investigation initiated \\
\hline 1997 & Bicycle tires & No investigation initiated \\
\hline 1997 & Ham & Withdrawn by petitioner \\
\hline 1997 & Toys & Final negative determination \\
\hline 1997 & Camping gear & No investigation initiated \\
\hline 1997 & Cardboard & No investigation initiated \\
\hline 1999 & Tires & No investigation initiated \\
\hline 2000 & $\begin{array}{l}\text { Electronic } \\
\text { converters }\end{array}$ & No investigation initiated \\
\hline 2000 & Small motorcycles & Positive injury determination \\
\hline 2000 & Canned peaches & Positive injury determination \\
\hline 2001 & Nuts and bolts & $\begin{array}{l}\text { Turned down by formality } \\
\text { problems }\end{array}$ \\
\hline 2002 & Wheat gluten & No investigation initiated \\
\hline
\end{tabular}

Source: Author's elaboration based on information presented in www.mecon.gov.ar/cnce and interviews.

Of the three industries where Argentina adopted safeguard measures (footwear, small motorcycles, and canned peaches), two were taken to the WTO Dispute Settlement Body. Footwear was the most visible case and on the basis of particular interpretations of WTO regulations, the Panel issued a decision against Argentina (Baracat and Nogués 2005). On the other hand, Argentina also lost the dispute against its measures in favor of the canned peach industry.

The evidence from Argentina's experience with safeguards under GATT Article XIX and the WTO Safeguards Agreement (SA), suggests that the government tried to operate safeguards as an economic instrument to facilitate the adjustment of industries damaged by increased imports but successive cases lost in WTO disputes acted as a barrier. This barrier 
has been interpreted by Sykes' (2003) ${ }^{39}$, argument that the WTO dispute settlement process never found a thread of economic reasoning on which to build its interpretations against safeguards. This interpretation helps to understand the outcome of the WTO dispute in the footwear case (Baracat and Nogués 2005).

\section{Textile and clothing safeguards}

Since 1993, the textile and clothing industry had also benefited from the DIEM's whose equivalent ad-valorem duties were in many cases, above $35 \%$. When the UR agreements came into force in 1995, several trading partners noted the inconsistency with Argentina's obligations and in response, the government attempted to provide protection on the basis of the transitional safeguard measures contemplated in the ATC.

Table V.7 shows the seven petitions for safeguards under this agreement: the CNCE found evidence of serious injury in only three cases: cotton textiles, polyester fibers, and polyester textiles. The other cases were turned down either because the request had not satisfied the procedural requirements, or simply because the information contained in the petitions indicated that the supporting evidence was too weak to merit these measures.

Table V.7

Safeguards under the ATC

\begin{tabular}{|l|l|l|}
\hline $\begin{array}{c}\text { Year of } \\
\text { Petition }\end{array}$ & \multicolumn{1}{|c|}{ Product } & Notes \\
\hline 1998 & Cotton textiles & $\begin{array}{l}\text { Positive injury } \\
\text { determination }\end{array}$ \\
\hline 1998 & Polyester fibers & $\begin{array}{l}\text { Positive injury } \\
\text { determination }\end{array}$ \\
\hline 1998 & Polyester textiles & Turned down \\
\hline 1998 & Polyester textiles & $\begin{array}{l}\text { Positive injury } \\
\text { determination }\end{array}$ \\
\hline 1998 & Rugs & Turned down \\
\hline 1998 & Fine textiles & Turned down \\
\hline 1998 & $\begin{array}{l}\text { Wool and synthetic fiber } \\
\text { pullovers }\end{array}$ & Turned down \\
\hline
\end{tabular}

Source: Authors's elaboration based on information of CNCE.

In order to understand the outcome of these safeguards, it is important to remind that the ATC seeks to dismantle the protection system under the Multi Fiber Agreements (MFA). As such, the measures regulated by its Article 6, are transitional safeguards that should be allowed only in exceptional and well justified cases. Under these requirements, the WTO Textile Monitoring Body (TMB) that clears these measures has taken a restrictive view and under these conditions, Argentina had to dismantle practically all of the measures it had imposed.

As was the case with the footwear industry, Argentina's textile producers were hard hit by the trade liberalization cum currency overvaluation. In addition, the lower wages in

\footnotetext{
39 "In the absence of any coherent theory as to when safeguards should be allowed, it is absurd to expect WTO members to produce a 'reasoned and adequate explanation as to how their measures are in compliance with the law" (Sykes 2003).
} 
Brazil was another negative external factor for this industry. In the end, textile producers had to face the full burden of adjustment as they were stripped from the possibility of receiving import-relief measures regulated by the $\mathrm{WTO}^{40}$.

\section{Summing-up}

Argentina's experience with safeguard investigation shows in the first place, that in assessing the safeguard petitions, the government followed a cautious economic approach. The CNCE took the leading role in turning down thirteen of the twenty petitions for safeguard protection both under GATT 94 Article XIX, and under Article 6 of the ATC. In spite of this careful approach, of the three cases that received safeguard protection under GATT Article XIX and the SA, two (footwear, and canned peaches) were turned down by the WTO DSB (dispute settlement body). Likewise, the Textile Monitoring Body (TMB) of the WTO turned down almost all of the transitional safeguard measures that Argentina had introduced in order to ease the adjustment process of textile producers. In short, the trade liberalization program was implemented under a system of regional and multilateral rules that practically made no room for the use of safeguards. We consider that this is a serious drawback that is likely to have back slashed against future liberalization attempts ${ }^{41}$.

Also, the case of Argentina appears to be a clear example where the frustrations with safeguards, has shifted demands for contingent protection to AD measures. We doubt that this is the type of outcome that negotiators were seeking when they drafted the WTO $\mathrm{AD}$ and SG agreements. We also doubt that this is the system of multilateral rules that will facilitate future trade liberalization attempts.

\section{Lessons}

Argentina's trade liberalization policies of the early 1990s were significant and, together with other important components of the reform program, played a major role in changing the economic trends of the country. Until 2001-2002 when trade policies were only partially reversed, the economy experienced the longest period with an open trade regime that it has seen in several decades. In relation to the previous experience, it is during these years when the demand and supply for antidumping and safeguards measures increased considerably. Our objective in this final section is to summarize the main lessons from our analysis of the factors that determined the use of these measures.

\section{Liberalization and contingent protection}

Unlike previous attempts, the trade liberalization policies that started to be implemented in the late 1980s have withstand the test of time; in some cases as the 20012003 period, turbulent times from which the country is only now emerging. Our conclusion is that along the adjustment process, $\mathrm{AD}$ and $\mathrm{SG}$ measures offered some importrelief but

\footnotetext{
40 The evidence from the media indicates that this industry has regrouped in order to resist any further liberalization proposals. In this regard, the absence of a workable safeguard instrument has had negative longrun effects.

${ }^{41}$ We also note from Table V.6, that after 2000, there have been only two new petitions for safeguards under Article XIX. We take this is an indication that the business community has given up its expectations that it can rely on this instrument.
} 
unlike past attempts, the latest liberalization policies have only been partially reversed by these or other measures. Our lesson here is that the country has realized that isolation is not good economic policy, and has accepted international discipline over trade policy in spite of the fact that some multilateral rules do not make economic sense.

\section{Currency overvaluation and contingent protection}

A misaligned exchange rate will make it impossible to sustain a technical approach to antidumping and safeguard investigations that calibrate on degree of displacement. In a situation of macro balance, injury analysis separates the few from the many; in a situation of imbalance the many are judged deserving of protection. Argentina made an explicit and careful attempt to isolate its trade remedies from protectionist interests through liberal rules and professional analysis. In 2001, after more than two years of recession and currency overvaluation, policymakers stretched the limits of the trade regime by increasing the tariff rates for consumer goods to the maximum allowed under its WTO obligations. This same situation, which increased imports beyond sustainable levels, resulted in a high share of technical reports by the CNCE indicating that an increasing number of industries were suffering serious injury. Following the devaluation of 2002 and strong growth in 2003, the number of $\mathrm{AD}$ and $\mathrm{SG}$ initiations declined significantly and now these instruments are functioning in an environment where they can distinguish better the petitions for protection.

\section{Flexibility of WTO-based AD regulations}

Important efforts in terms of time and resources were invested in order to ensure that the AD legislation would distill "frivolous" petitions for protection. In spite of these efforts, the lesson from the experience of Argentina indicates the tremendous flexibility that WTO-based AD regulations have for adapting to the political and economic cycles. Argentina maintained a technical approach to AD investigations, but as the economy worsened, the mechanism delivered information signaling the need for increasing protection and this happened without changing a single comma of the regulations. Argentina adopted several of the more liberal options allowed by the rules and although they did not prevent implementation of measures, the liberal provisions, such as lesser duties, resulted in lower AD barriers.

\section{Political economy implications of multilateral safeguard regulations}

Essentially during and following the implementation of the trade liberalization program, Argentina functioned without a safeguard mechanism. Because of the high standards required for their application and the lack of an economic basis in the jurisprudence that has been established by the WTO appeal body, safeguards under GATT Article XIX and the SA, as well as the textile transitional safeguards, were nearly useless to the business community. The tentative lesson is that the political economy of these high safeguard standards may in the medium run work against further trade liberalization programs and/or in favor of the establishment of more obscure barriers.

It is of interest to compare the WTO rules on safeguards with the WTO rules for the special agricultural safeguards demanded by industrial countries when they accepted the tariffication of non-tariff measures under the Agreement on Agriculture (WTO 1996). This tariffication had practically no liberalization in it (Anderson 1996), and still special agricultural safeguards were necessary to "sell" the shift of policy instruments to the agricultural interest groups of OECD countries. The big difference is that unlike GATT 
Article XIX safeguards, the special agricultural safeguards have automatic trigger mechanisms.

\section{Safeguards and $A D$ in the Mercosur}

Given the ban on safeguards for intra-Mercosur trade, policymakers and the business community have resorted to antid umping and other more obscure forms of nontariff-barriers (Berlinski 2001). Argentina's experience indicates that it made no reserves for its sensitive industries either in the Uruguay Round, or in the Mercosur negotiations. Because of this, the government continues to face demands for import relief from relatively labor-intensive sectors. As the Brazilian industry has sufficient industrial capacity to overwhelm Argentine producers, under Mercosur's trade regulations, this country has a privileged position. The lesson here is that Argentina should have either made reserves in the Mercosur, and/or should have negotiated a special regional safeguard as the Andean Community has (Reina 2004). The current situation has created and will continue to create frictions, and/or what is worse, will result in the establishment of ad-hoc measures like voluntary export restraints.

\section{Political determination and the demand for $A D$ protection}

Another lesson refers to factors having negative impacts on the number of AD petitions. In addition to the obvious like the legal costs and time involved in an investigation, other factors like the political determination not to process AD petitions while the economy was still under high inflation in the early 1990s, and the unbounded time that officials had to open an investigation under the previous regulations, had negative effects on the demand for AD measures. Although it is impossible to determine with precision how many companies/industries considered to submit a petition and in the end decided against, it is of interest to note that by the consideration of one key informant, around $50 \%$ of all potential petitions were finally not submitted. This is a clear example of the role played by the perceptions of the business community regarding the policy preferences and political determination in favor of openness held by the government during the initial years of the trade liberalization program.

\section{Resource constraints}

The administrative and institutional reforms implemented in order to administer the WTO AD and SG regulations demanded an important investment in human and financial resources. In spite of this, the operating budgets have often been insufficient to do the job as expected. For example, because of insufficient funds, in only a handful of cases have insitu verifications of dumping margins been undertaken. Likewise, in the creation of the $\mathrm{CNCE}$, the government was careful in the qualifications required for staff appointments. Nevertheless, this Commission as well as the UGE have not always been successful in offering wages attractive enough to retain staff; there are also clear unmet needs in terms of training and infrastructure including information technology. These factors can eventually undermine the capacity to maintain a technical approach in the investigations. 


\section{BIBLIOGRAPHY}

ALADI (2002), Probable Impacto que Tendrían los Acuerdos con la Unión Europea en el Comercio Intrarregional y en el Comercio de los Países Miembros con los Países de Europa, ALADI/SEC/Estudio 149.

ANDERSON, K. (1996), Strengthening the Global Trading System: From GATT to WTO, Centre for International Economic Studies, University of Adelaide: Australia.

BARACAT, E. AND J. NOGUÉS (2005), Safeguards and Trade Liberalization: Lessons from the Argentine Experience in the Footwear Industry, World Bank Staff Working Paper (forthcoming).

BERLINSKI, J. et. al. (2001), Sobre el Beneficio de la Integración Plena en el MERCOSUR, Siglo XXI: Madrid.

DE LA TORRE, A., E. LEVI YEYATI AND S. SCHMUKLER (2003), Living and Dying with Hard Pegs: The Rise and Fall of Argentina's Currency Board, Economia, Vol. 5, No. 2 .

FINGER, J. M., (1993), Antidumping: How it Works and Who Gets Hurt, The University of Michigan Press.

FINGER, J. M., AND J. NOGUÉS, (1987), International Control of Subsidies and Countervailing Duties, World Bank Economic Review Vol. I (September).

FINGER, J. AND T. MURRAY (1990), Policing Unfair Imports: The US Example, Working Paper Series 401, The World Bank.

FRANCOIS, J. AND G. NIELS (1993), Business Cycles, the Current Account and Administered Protection in Mexico, CEPR, Discussion Paper Series \# 3981.

GATT (1986), The Tokyo Round Agreements, GATT.

GIORGI, D. (2001), Acerca del Nuevo Decreto Antidumping y Antisubvenciones, La Nación, 11 de Septiembre de 2001.

HORLICK, G. (1992), Argentina: Draft Antidumping Regulations.

IRWIN, D. (2002), Free Trade Under Fire, Princeton University Press, Princeton: New Jersey.

KRUEGER, A. (1995), American Trade Policy: A Tragedy in the Making, American Enterprise Institute: Washington D.C. 
NOGUÉS, J. (1986), The Nature of Argentina's Policy Reforms During 1976-1981, Staff Working Paper No. 765, The World Bank.

NOGUÉS, J. (1991), Less Than Fair Value Trade Cases Against Latin American Countries, The World Economy, December.

NOGUÉS, J. (2001), La Institucionalización de la Globalización in j. De Pablo, J. Nogués and R. Dornbusch, La Globalización, la Argentina y Cada Uno de Nosotros, Consejo Empresario Argentino.

NOGUÉS, J. (2003), US Contingent Protection Measures Against Honey Imports:

Regulations, Development and the Doha Round, World Bank Staff Working Paper No 3,088, (www.worldbank.org).

PRUSA, T. (1992), Why Are So Many Antidumping Petitions Withdrawn?, Journal of International Economics, vol.33:1-20.

REINA, M. (2004), Aplicación de Salvaguardias y Derechos Antidumping en Colombia, mimeo.

SANGUINETTI, P. AND M. SALUSTRO (1999), MERCOSUR y el Sesgo Regional de la Política Comercial: Aranceles y Barreras no Tarifarias, mimeo: Buenos Aires.

SYKES, A. (2003), The Safeguard Mess: A Critique of WTO Jurisprudence, World Trade Review, 2(3).

UNIÓN INDUSTRIAL ARGENTINA (1992?), Proyecto de Decreto Reglamentario a la Ley 24176, UIA: Buenos Aires.

WORLD TRADE ORGANIZATION (1996), The Results of the Uruguay Round of Multilateral Trade Negotiations, WTO: Geneva. 
ANNEX 1: Information on Argentina's Antidumping Investigations: 1995-2004

\begin{tabular}{|c|c|c|c|c|c|c|c|c|c|c|c|}
\hline & & & & & Injury & & & ntidumpir & & & \\
\hline $\begin{array}{c}\text { Year of } \\
\text { Presentation }\end{array}$ & Product & Industry & Origin & $\begin{array}{l}\text { Date } \\
\text { Opened }\end{array}$ & Preliminary & Final & $\begin{array}{c}\text { Dumping } \\
\text { Margin } \\
(\%)\end{array}$ & $\begin{array}{c}\text { Duty } \\
\text { Criteria }\end{array}$ & Methodology & $\begin{array}{c}\text { Date Final } \\
\text { Decision } \\
\text { Published } \\
\end{array}$ & Notes \\
\hline $01 / 1995$ & Fireworks & $\mathrm{O}$ & China & $30 / 07 / 1996$ & $\mathrm{~W}$ & $+/-$ & $\begin{array}{r}87- \\
550 \\
\end{array}$ & FD & $\mathrm{TC}$ & $27 / 05 / 1998$ & \\
\hline $02 / 1995$ & Steel ware & S\&SP & China & $07 / 11 / 1995$ & + & + & $\begin{array}{l}81- \\
637 \\
\end{array}$ & FD & $\mathrm{TC}$ & $17 / 02 / 1998$ & \\
\hline $03 / 1995$ & Metal sheet & S\&SP & China & $02 / 11 / 1995$ & + & + & $\begin{array}{r}208- \\
242\end{array}$ & FD & $\mathrm{TC}$ & 08/10/1997 & \\
\hline $05 / 1995$ & $\begin{array}{l}\text { Atrazine } \\
\text { (herbicide) }\end{array}$ & $\mathrm{Ch}$ & South Africa & $27 / 10 / 1995$ & - & N/A & --- & --- & -- & $07 / 05 / 1996$ & $\mathrm{C}$ \\
\hline 06/1995 & Pipe parts & S\&SP & $\begin{array}{l}\text { China, } \\
\text { Taiwan }\end{array}$ & $30 / 10 / 1995$ & $\mathrm{~W}$ & + & -- & --- & -- & $14 / 10 / 1997$ & \\
\hline $08 / 1995$ & Chain saws & S\&SP & China & $31 / 10 / 1995$ & + & + & -- & --- & -- & 08/10/1997 & \\
\hline $11 / 1995$ & Electric cables & EE & $\begin{array}{l}\text { Brazil, } \\
\text { France, } \\
\text { Spain, South } \\
\text { Africa }\end{array}$ & 20/02/1996 & W & + & --- & --- & --- & $31 / 03 / 1998$ & \\
\hline $12 / 1995$ & $\begin{array}{l}\text { Fluorescent } \\
\text { lamps }\end{array}$ & $\mathrm{EE}$ & Brazil, Chile & $31 / 10 / 1995$ & + & N/A & --- & --- & -- & $21 / 08 / 1996$ & $\mathrm{U}$ \\
\hline $18 / 1995$ & $\begin{array}{l}\text { Electromechanic } \\
\text { products }\end{array}$ & EE & Uruguay & $07 / 12 / 1995$ & $\mathrm{~W}$ & - & --- & --- & -- & 01/07/1997 & \\
\hline $20 / 1995$ & Fuses & $\mathrm{EE}$ & Brazil & 28/12/1995 & + & $+/-$ & $\begin{array}{r}73- \\
449\end{array}$ & FD & DM & $16 / 12 / 1997$ & \\
\hline $22 / 1995$ & Tire parts & R\&RP & Germany & $24 / 09 / 1996$ & - & N/A & $\overline{---}$ & --- & --- & 19/06/1997 & $\mathrm{C}$ \\
\hline $26 / 1995$ & Wheat spaghettis & PF & Chile & $27 / 10 / 1995$ & $\mathrm{~W}$ & - & --- & --- & --- & $05 / 03 / 1997$ & \\
\hline 29/1995 & $\begin{array}{l}\text { Motor } \\
\text { compressors } \\
\end{array}$ & M\&NEE & Brazil & $17 / 01 / 1995$ & $\mathrm{~W}$ & - & -- & --- & -- & $24 / 12 / 1997$ & \\
\hline $38 / 1995$ & Chain saws & S\&SP & Brazil & $31 / 10 / 1995$ & + & + & --- & --- & --- & $06 / 05 / 1997$ & \\
\hline $41 / 1995$ & Ceramic magnets & $\mathrm{O}$ & Brazil & $02 / 11 / 1995$ & + & + & --- & --- & $\mathrm{DM}$ & $11 / 04 / 1997$ & \\
\hline $52 / 1995$ & Drill & M\&NEE & China & 05/12/1995 & + & $+/-$ & $208-242$ & --- & $\mathrm{TC}$ & 08/10/1997 & \\
\hline $56 / 1995$ & Milling machine & M\&NEE & $\begin{array}{l}\text { China, } \\
\text { Taiwan }\end{array}$ & 13/03/1997 & + & + & $10-66$ & $\begin{array}{l}\text { FD } \\
\text { FD }\end{array}$ & $\begin{array}{r}\mathrm{TC} \\
\mathrm{DM}\end{array}$ & 05/11/1998 & \\
\hline
\end{tabular}




\begin{tabular}{|c|c|c|c|c|c|c|c|c|c|c|c|}
\hline & & & & & Injur: & & & ntidumpin & & & \\
\hline $\begin{array}{c}\text { Year of } \\
\text { Presentation }\end{array}$ & Product & Industry & Origin & $\begin{array}{l}\text { Date } \\
\text { Opened }\end{array}$ & Preliminary & Final & $\begin{array}{c}\text { Dumping } \\
\text { Margin } \\
(\%)\end{array}$ & $\begin{array}{c}\text { Duty } \\
\text { Criteria }\end{array}$ & Methodology & \begin{tabular}{|c|}
$\begin{array}{c}\text { Date Final } \\
\text { Decision } \\
\text { Published }\end{array}$ \\
\end{tabular} & Notes \\
\hline $63 / 1995$ & $\begin{array}{l}\text { DTPA } \\
\text { pentasodic }(40 \%)\end{array}$ & $\mathrm{Ch}$ & $\begin{array}{l}\text { Netherlands, } \\
\text { United States }\end{array}$ & $28 / 12 / 1995$ & $\mathrm{~W}$ & - & --- & --- & --- & 02/05/1997 & \\
\hline 64/1995 & $\begin{array}{l}\text { EDTA tetrasodic } \\
(39 \%)\end{array}$ & $\mathrm{Ch}$ & \begin{tabular}{|l} 
Germany, \\
Netherlands, \\
United States \\
\end{tabular} & $28 / 12 / 1995$ & $\mathrm{~W}$ & - & \begin{tabular}{ll|}
-- \\
\end{tabular} & ---- & --- & 05/05/1997 & \\
\hline $65 / 1995$ & $\begin{array}{l}\text { EDTA powder } \\
\text { calcium }\end{array}$ & $\mathrm{Ch}$ & \begin{tabular}{|l} 
Germany, \\
Netherlands \\
\end{tabular} & 28/12/1995 & $\mathrm{W}$ & - & --- & --- & --- & 05/05/1997 & \\
\hline $66 / 1995$ & $\begin{array}{l}\text { EDTA tetrasodic } \\
(66 \%)\end{array}$ & $\mathrm{Ch}$ & \begin{tabular}{|l|} 
Brazil, \\
Germany, \\
Netherlands \\
\end{tabular} & $28 / 12 / 1995$ & $\mathrm{~W}$ & - & --- & --- & --- & $05 / 05 / 1997$ & \\
\hline $67 / 1995$ & EDTA acid & $\mathrm{Ch}$ & $\begin{array}{l}\text { Netherlands, } \\
\text { United States } \\
\end{array}$ & 04/01/1996 & - & N/A & --- & -- & --- & 01/11/1996 & C \\
\hline $68 / 1995$ & \begin{tabular}{|l|} 
Washing \\
machine motors
\end{tabular} & M\&NEE & $\begin{array}{l}\text { Republic of } \\
\text { Korea }\end{array}$ & $05 / 12 / 1995$ & + & + & $27-31$ & --- & DM & $26 / 01 / 1998$ & \\
\hline $69 / 1995$ & Color TVs & $\mathrm{CD}$ & \begin{tabular}{|l|} 
China \\
\end{tabular} & $25 / 04 / 1996$ & $\mathrm{~W}$ & - & --- & --- & --- & 20/08/1997 & \\
\hline $76 / 1995$ & Playing cards & $\mathrm{O}$ & China & 23/05/1996 & + & + & \begin{tabular}{|l|}
$371-$ \\
1033 \\
\end{tabular} & FD & $\mathrm{TC}$ & $17 / 02 / 1998$ & \\
\hline $78 / 1995$ & $\begin{array}{l}\text { Aluminum } \\
\text { Chloride }\end{array}$ & Ch & United States & $23 / 05 / 1996$ & + & - & --- & --- & --- & 10/11/1997 & \\
\hline $82 / 1995$ & Car stereos & $\mathrm{CD}$ & China & 06/05/1996 & $\mathrm{W}$ & + & $\begin{array}{r}34- \\
138 \\
\end{array}$ & FD & $\mathrm{TC}$ & 11/11/1997 & \\
\hline $86 / 1995$ & Gas carafe & $\mathrm{O}$ & Brazil & 19/04/1996 & + & + & 15 & FD & DM & 26/01/1998 & \\
\hline $87 / 1995$ & Polystyrene trays & P\&PP & Brazil & 09/05/1996 & + & N/A & --- & -- & -- & $10 / 06 / 1997$ & $\mathrm{U}$ \\
\hline $90 / 1995$ & Gas meters & $\mathrm{EE}$ & \begin{tabular}{|l|} 
Italy \\
\end{tabular} & $27 / 08 / 1996$ & + & - & --- & --- & --- & $07 / 01 / 1998$ & \\
\hline $02 / 1996$ & \begin{tabular}{|l|} 
Sea sticks \\
\end{tabular} & $\mathrm{PF}$ & \begin{tabular}{|l|} 
Thailand \\
\end{tabular} & \begin{tabular}{|l|}
$28 / 08 / 1996$ \\
\end{tabular} & $\mathrm{~W}$ & - & --- & --- & 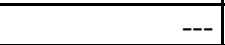 & \begin{tabular}{|l|}
$17 / 11 / 1997$ \\
\end{tabular} & \\
\hline $06 / 1996$ & Cement bags & W\&PP & $\begin{array}{l}\text { Brazil, South } \\
\text { Africa } \\
\end{array}$ & $23 / 05 / 1996$ & + & - & --- & --- & --- & $10 / 11 / 1997$ & \\
\hline $07 / 1996$ & Locks & S\&SP & China & $30 / 07 / 1996$ & + & + & $\begin{array}{r}98- \\
390 \\
\end{array}$ & FD & $\mathrm{TC}$ & 09/06/1998 & \\
\hline 19/1996 & Rays \& niples & S\&SP & \begin{tabular}{|l|} 
China, \\
Taiwan
\end{tabular} & $17 / 10 / 1996$ & $\mathrm{~W}$ & + & $44-271$ & $\begin{array}{l}\mathrm{FD} \\
\mathrm{FD}\end{array}$ & $\begin{array}{r}\mathrm{TC} \\
\mathrm{DM} \\
\end{array}$ & $21 / 07 / 1998$ & \\
\hline $22 / 1996$ & Electric isolators & $\mathrm{EE}$ & India & $30 / 08 / 1996$ & - & N/A & --- & --- & -- & $22 / 05 / 1997$ & C \\
\hline $32 / 1996$ & Bathroom faucets & S\&SP & China & $21 / 10 / 1996$ & + & - & --- & --- & -- & \begin{tabular}{|l|l|l}
$08 / 01 / 1998$ \\
\end{tabular} & \\
\hline
\end{tabular}




\begin{tabular}{|c|c|c|c|c|c|c|c|c|c|c|c|}
\hline & & & & & Injur: & & & ntidumpir & & & \\
\hline $\begin{array}{c}\text { Year of } \\
\text { Presentation }\end{array}$ & Product & Industry & Origin & $\begin{array}{l}\text { Date } \\
\text { Opened }\end{array}$ & Preliminary & Final & $\begin{array}{c}\text { Dumping } \\
\text { Margin } \\
(\%)\end{array}$ & $\begin{array}{c}\text { Duty } \\
\text { Criteria }\end{array}$ & Methodology & \begin{tabular}{|c|} 
Date Final \\
Decision \\
Published \\
\end{tabular} & Notes \\
\hline $42 / 1996$ & Wood & W\&PP & Paraguay & $06 / 03 / 1997$ & $+/-$ & $+/-$ & $5-50$ & $\mathrm{LD}$ & DM & $22 / 01 / 1999$ & \\
\hline $43 / 1996$ & $\begin{array}{l}\text { Fiber optic } \\
\text { cables }\end{array}$ & $\mathrm{EE}$ & $\begin{array}{l}\text { Brazil, Spain, } \\
\text { United States }\end{array}$ & $21 / 02 / 1997$ & W & + & $10-172$ & $\begin{array}{l}\mathrm{LD} \\
\mathrm{LD} \\
\mathrm{LD} \\
\end{array}$ & $\begin{array}{l}\text { DM } \\
\text { DM } \\
\text { DM } \\
\end{array}$ & $18 / 12 / 1998$ & \\
\hline $48 / 1996$ & Door locks & S\&SP & China & 25/03/1997 & $\mathrm{W}$ & - & --- & --- & -- & $30 / 06 / 1998$ & \\
\hline $52 / 1996$ & \begin{tabular}{|l|} 
Drill bit \\
\end{tabular} & S\&SP & Italy & $21 / 02 / 1997$ & $\mathrm{~W}$ & + & 113-176 & FD & DM & \begin{tabular}{|l|l|}
$11 / 09 / 1998$ \\
\end{tabular} & \\
\hline $68 / 1996$ & Gas meters & $\mathrm{EE}$ & Brazil & $09 / 09 / 1997$ & - & N/A & --- & --- & -- & $15 / 04 / 1998$ & $\mathrm{C}$ \\
\hline $70 / 1996$ & Chain saw blades & S\&SP & \begin{tabular}{|l|} 
Sweden, \\
United \\
Kingdom \\
\end{tabular} & $11 / 08 / 1997$ & + & N/A & --- & --- & --- & $17 / 05 / 1999$ & $\overline{\mathrm{U}}$ \\
\hline $72 / 1996$ & Vaseline & $\mathrm{O}$ & United States & 16/04/1997 & - & N/A & --- & --- & --- & 09/01/1998 & C \\
\hline $15 / 1997$ & Coated cardboard & W\&PP & Germany & $27 / 08 / 1997$ & + & + & 13-35 & $\mathrm{FD}$ & $\mathrm{DM}$ & $26 / 02 / 1999$ & \\
\hline $34 / 1997$ & Sea sticks & $\mathrm{PF}$ & \begin{tabular}{|l} 
Republic of \\
Korea
\end{tabular} & 07/01/1998 & - & N/A & -- & -- & -- & 01/09/1998 & $\mathrm{C}$ \\
\hline $35 / 1997$ & Chains & S\&SP & Brazil & 11/12/1997 & + & N/A & --- & -- & --- & $12 / 06 / 1999$ & $\mathrm{U}$ \\
\hline $43 / 1997$ & $\begin{array}{l}\text { Eviscerated } \\
\text { chicken }\end{array}$ & $\mathrm{PF}$ & Brazil & $25 / 01 / 1999$ & $\mathrm{~W}$ & + & $8-15$ & FD & $\overline{\mathrm{DM}}$ & $24 / 07 / 2000$ & \\
\hline $45 / 1997$ & Abrasives & $\mathrm{O}$ & Brazil & $27 / 04 / 1998$ & + & N/A & --- & --- & --- & \begin{tabular}{|l|}
$10 / 06 / 1999$ \\
\end{tabular} & $\mathrm{U}$ \\
\hline $31 / 1998$ & \begin{tabular}{|l|} 
Tiles \\
\end{tabular} & $\mathrm{O}$ & Italy & 25/09/1998 & $\mathrm{W}$ & $+/-$ & $10-43$ & LD & DM & 17/11/1999 & \\
\hline $48 / 1998$ & Javelins & $\mathrm{O}$ & Brazil & $18 / 02 / 1999$ & + & + & 39 & FD & DM & $26 / 06 / 2000$ & \\
\hline 51/1998 & $\begin{array}{l}\text { Flat laminated } \\
\text { products }\end{array}$ & S\&SP & \begin{tabular}{|l|} 
Brazil, \\
Russia, \\
Ukraine \\
\end{tabular} & $05 / 10 / 1998$ & $+/-$ & + & $9-70$ & $\begin{array}{l}\mathrm{LD} \\
\mathrm{LD} \\
\mathrm{LD} \\
\end{array}$ & $\begin{array}{r}\text { DM } \\
\text { TC } \\
\text { TC } \\
\end{array}$ & $09 / 12 / 1999$ & \\
\hline $52 / 1998$ & \begin{tabular}{|l} 
Flat glass \\
\end{tabular} & $\mathrm{O}$ & China & 25/01/1999 & - & N/A & --- & --- & -- & $02 / 07 / 1999$ & $\mathrm{C}$ \\
\hline $61 / 1998$ & Wooden hangers & $\mathrm{CD}$ & China & 24/03/1999 & $\mathrm{W}$ & + & 475 & FD & $\mathrm{TC}$ & $07 / 08 / 2000$ & \\
\hline $67 / 1998$ & Denim & T\&TP & Brazil & $29 / 04 / 1999$ & $\mathrm{~W}$ & + & --- & $\begin{array}{ll}-- \\
\end{array}$ & --- & $01 / 11 / 2000$ & \\
\hline $68 / 1998$ & Drill bit & S\&SP & China & $10 / 06 / 1999$ & + & + & $199-916$ & FD & TC & $16 / 08 / 2000$ & \\
\hline 69/1998 & PVC & P\&PP & \begin{tabular}{|l} 
Mexico, \\
United \\
States \\
\end{tabular} & 21/04/1999 & + & + & $\begin{array}{r}9- \\
30\end{array}$ & $\begin{array}{l}\text { FD } \\
\text { FD }\end{array}$ & -- & $24 / 04 / 2000$ & \\
\hline
\end{tabular}




\begin{tabular}{|c|c|c|c|c|c|c|c|c|c|c|c|}
\hline & & & & & Injur: & & & Intidumpir & & & \\
\hline $\begin{array}{c}\text { Year of } \\
\text { Presentation }\end{array}$ & Product & Industry & Origin & $\begin{array}{c}\text { Date } \\
\text { Opened }\end{array}$ & Preliminary & Final & $\begin{array}{c}\text { Dumping } \\
\text { Margin } \\
(\%)\end{array}$ & $\begin{array}{c}\text { Duty } \\
\text { Criteria }\end{array}$ & Methodology & $\begin{array}{c}\text { Date Final } \\
\text { Decision } \\
\text { Published } \\
\end{array}$ & Notes \\
\hline 76/1998 & \begin{tabular}{|l} 
Nylon and \\
Polyester fabric
\end{tabular} & $\mathrm{T} \& \mathrm{TP}$ & $\begin{array}{l}\text { Republic of } \\
\text { Korea }\end{array}$ & $22 / 06 / 1999$ & + & + & $\begin{array}{r}98- \\
197 \\
\end{array}$ & FD & -- & $22 / 06 / 2000$ & \\
\hline $23 / 1999$ & Cardboard & W\&PP & $\begin{array}{l}\text { Austria, Italy, } \\
\text { Poland, South } \\
\text { Africa, Spain, } \\
\text { Sweden }\end{array}$ & $29 / 07 / 1999$ & $\mathrm{~W}$ & + & $21-60$ & $\begin{array}{r}\mathrm{LD} \\
0 \\
\mathrm{LD} \\
0 \\
\\
\mathrm{LD} \\
\mathrm{LD} \\
\end{array}$ & $\begin{array}{l}\text { DM } \\
\text { DM } \\
\text { DM } \\
\text { DM } \\
\\
\text { DM } \\
\text { DM } \\
\end{array}$ & $23 / 11 / 2000$ & \\
\hline $26 / 1999$ & \begin{tabular}{|l|} 
Steel sheets \\
\end{tabular} & S\&SP & \begin{tabular}{|l|} 
Brazil \\
\end{tabular} & \begin{tabular}{|l|}
$13 / 05 / 1999$ \\
\end{tabular} & N/A & + & --- & $\mathrm{FD}$ & $\mathrm{DM}$ & $05 / 05 / 2000$ & $\mathrm{R}$ \\
\hline $33 / 1999$ & \begin{tabular}{|l|}
$\begin{array}{l}\text { Steel sheets } \\
\text { blades }\end{array}$ \\
\end{tabular} & S\&SP & Mexico & $16 / 09 / 1999$ & + & N/A & \begin{tabular}{ll|}
-- \\
\end{tabular} & $\begin{array}{ll}-- \\
\end{array}$ & --- & $01 / 03 / 2001$ & $\overline{\mathrm{U}}$ \\
\hline $\begin{array}{l}36 / 1999 \\
(71 / 2001) \\
\end{array}$ & $\begin{array}{l}\text { Cold laminated } \\
\text { products }\end{array}$ & S\&SP & Brazil, Russia & $02 / 09 / 1999$ & $+/-$ & + & --- & $\begin{array}{l}\mathrm{LD} \\
\mathrm{FD} \\
\end{array}$ & --- & $02 / 03 / 2001$ & \\
\hline $44 / 1999$ & Pipe accessories & S\&SP & \begin{tabular}{|l|} 
China, \\
Taiwan \\
\end{tabular} & $26 / 10 / 1999$ & N/A & + & 104-338 & FD & $\begin{array}{r}\text { TC } \\
\text { DM } \\
\end{array}$ & $12 / 10 / 2000$ & $\mathrm{R}$ \\
\hline $47 / 1999$ & Acetate textiles & $\mathrm{T} \& \mathrm{TP}$ & \begin{tabular}{|l|} 
Republic of \\
Korea, \\
Taiwan \\
\end{tabular} & $02 / 12 / 1999$ & + & + & 26 & $\begin{array}{l}\text { FD } \\
\text { FD }\end{array}$ & $\begin{array}{l}\text { DM } \\
\text { DM }\end{array}$ & $01 / 06 / 2001$ & \\
\hline $53 / 1999$ & Polyethylene & $P \& P P$ & \begin{tabular}{|l} 
Australia, \\
Indonesia, \\
Republic of \\
Korea, \\
Venezuela \\
\end{tabular} & $15 / 02 / 2000$ & - & N/A & --- & --- & -- & $02 / 08 / 2000$ & C \\
\hline $54 / 1999$ & \begin{tabular}{|l|} 
Polystyrene trays \\
\end{tabular} & $\mathrm{P} \& \mathrm{PP}$ & Chile & $15 / 02 / 2000$ & + & + & $9-17$ & $\mathrm{FD}$ & $\mathrm{DM}$ & $15 / 08 / 2001$ & \\
\hline $57 / 1999$ & Chain saws & S\&SP & China & 26/10/1999 & N/A & + & --- & LD & $\mathrm{TC}$ & $18 / 10 / 2000$ & $\mathrm{R}$ \\
\hline 62/1999 & $\begin{array}{l}\text { Hot laminated } \\
\text { bars }\end{array}$ & S\&SP & \begin{tabular}{|l} 
Czech \\
Republic, \\
South Africa, \\
Turkey
\end{tabular} & $08 / 06 / 2000$ & + & $+/-$ & $21-39$ & \begin{tabular}{r|} 
\\
0 \\
0 \\
$\mathrm{LD}$
\end{tabular} & \begin{tabular}{l|}
$\mathrm{DM}$ \\
$\mathrm{DM}$ \\
$\mathrm{DM}$
\end{tabular} & $23 / 10 / 2001$ & \\
\hline $63 / 1999$ & Calcium carbide & $\mathrm{Ch}$ & Poland & $29 / 05 / 2000$ & W & + & 10 & $\mathrm{FD}$ & DM & $21 / 11 / 2001$ & \\
\hline
\end{tabular}




\begin{tabular}{|c|c|c|c|c|c|c|c|c|c|c|c|}
\hline & & & & & Injur: & & & ntidumpin & & & \\
\hline $\begin{array}{c}\text { Year of } \\
\text { Presentation }\end{array}$ & Product & Industry & Origin & $\begin{array}{c}\text { Date } \\
\text { Opened }\end{array}$ & Preliminary & Final & $\begin{array}{c}\text { Dumping } \\
\text { Margin } \\
(\%)\end{array}$ & $\begin{array}{c}\text { Duty } \\
\text { Criteria }\end{array}$ & Methodology & $\begin{array}{c}\text { Date Final } \\
\text { Decision } \\
\text { Published } \\
\end{array}$ & Notes \\
\hline 65/1999 & \begin{tabular}{|l|} 
Hot laminated \\
steel cross- \\
sections
\end{tabular} & S\&SP & $\begin{array}{l}\text { Brazil, Czech } \\
\text { Republic, } \\
\text { South Africa, } \\
\text { Turkey }\end{array}$ & $11 / 07 / 2000$ & + & + & $2-64$ & $\begin{array}{l}\mathrm{LD} \\
\mathrm{LD} \\
\mathrm{LD} \\
\mathrm{LD} \\
\end{array}$ & $\begin{array}{l}\mathrm{DM} \\
\mathrm{DM} \\
\mathrm{DM} \\
\mathrm{DM}\end{array}$ & \begin{tabular}{|l|}
$11 / 01 / 2002$ \\
\end{tabular} & \\
\hline 66/1999 & \begin{tabular}{|l|} 
Steel disks \\
\end{tabular} & S\&SP & Spain & $02 / 05 / 2000$ & + & + & $99-114$ & LD & $\overline{\mathrm{DM}}$ & $30 / 07 / 2001$ & \\
\hline $01 / 2000$ & $\begin{array}{l}\text { Laminated steel } \\
\text { or iron products }\end{array}$ & S\&SP & $\begin{array}{l}\text { Kazakhstan, } \\
\text { Romania, } \\
\text { Slovakia, } \\
\text { South Africa } \\
\end{array}$ & $30 / 10 / 2000$ & + & + & $40-88$ & $\begin{array}{l}\text { FD } \\
\text { FD } \\
\text { FD } \\
\text { FD }\end{array}$ & $\begin{array}{r}\text { CB:Canada } \\
\text { CB: Canada } \\
\text { DM } \\
\text { DM }\end{array}$ & $30 / 04 / 2002$ & \\
\hline $27 / 2000$ & $\begin{array}{l}\begin{array}{l}\text { Washing } \\
\text { machines }\end{array} \\
\end{array}$ & $\mathrm{CD}$ & \begin{tabular}{|l} 
Brazil, \\
Italy, \\
Spain
\end{tabular} & $29 / 08 / 2000$ & $\mathrm{~W}$ & + & $9-20$ & $\begin{array}{r}0 \\
\mathrm{FD} \\
\mathrm{FD}\end{array}$ & $\begin{array}{l}\text { DM } \\
\text { DM } \\
\text { DM }\end{array}$ & $28 / 02 / 2002$ & \\
\hline $38 / 2000$ & Bicycles & $\mathrm{CD}$ & \begin{tabular}{|l} 
China, \\
Taiwan \\
\end{tabular} & $16 / 08 / 2000$ & N/A & + & --- & $\begin{array}{l}\text { LD } \\
\text { LD }\end{array}$ & $\begin{array}{r}\mathrm{TC} \\
\mathrm{DM}\end{array}$ & $24 / 05 / 2002$ & $\mathrm{R}$ \\
\hline $39 / 2000$ & \begin{tabular}{|l|} 
Granulated steel \\
\end{tabular} & S\&SP & Brazil, Spain & \begin{tabular}{|l|}
$27 / 09 / 2000$ \\
\end{tabular} & + & + & --- & --- & --- & $18 / 04 / 2002$ & \\
\hline $42 / 2000$ & \begin{tabular}{|l|} 
Fiber glass \\
products
\end{tabular} & $\mathrm{O}$ & $\begin{array}{l}\text { Chile, } \\
\text { South Africa }\end{array}$ & $18 / 10 / 2000$ & + & + & $\begin{array}{c}39- \\
105 \\
\end{array}$ & $\begin{array}{l}\text { FD } \\
\text { FD }\end{array}$ & $\begin{array}{l}\mathrm{DM} \\
\mathrm{DM}\end{array}$ & $18 / 04 / 2002$ & \\
\hline $46 / 2000$ & $\begin{array}{l}\text { Electrolytic } \\
\text { copper wire }\end{array}$ & $\overline{\mathrm{EE}}$ & Chile & $17 / 08 / 2000$ & + & + & 9-17 & FD & $\overline{\mathrm{DM}}$ & $19 / 12 / 2001$ & \\
\hline $47 / 2000$ & Steel tubes & S\&SP & Japan & $15 / 12 / 2000$ & + & + & 55 & FD & 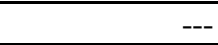 & $14 / 12 / 2001$ & \\
\hline $57 / 2000$ & Rays \& niples & S\&SP & $\begin{array}{l}\text { China, } \\
\text { Taiwán }\end{array}$ & $24 / 07 / 2000$ & N/A & + & --- & $\begin{array}{l}\text { FD } \\
\text { FD }\end{array}$ & $\begin{array}{r}\mathrm{TC} \\
\mathrm{DM}\end{array}$ & $23 / 07 / 2001$ & $\mathrm{R}$ \\
\hline $59 / 2000$ & Carafes & S\&SP & Brazil & $24 / 01 / 2001$ & N/A & + & --- & --- & -- & $24 / 07 / 2002$ & $\mathrm{R}$ \\
\hline $62 / 2000$ & Phenol panels & $\mathrm{O}$ & Brazil & $08 / 11 / 2000$ & + & + & --- & --- & --- & \begin{tabular}{|l|}
$09 / 05 / 2002$ \\
\end{tabular} & \\
\hline 64/2000 & Thermos & $\mathrm{CD}$ & \begin{tabular}{|l|} 
China \\
\end{tabular} & $27 / 10 / 2000$ & + & + & 215 & FD & $\mathrm{TC}$ & $29 / 10 / 2001$ & \\
\hline $67 / 2000$ & $\begin{array}{l}\text { Polypropylene } \\
\text { fabric }\end{array}$ & T\&TP & Chile & $21 / 11 / 2000$ & + & + & 58 & FD & DM & $22 / 05 / 2002$ & \\
\hline $70 / 2000$ & Drill bits & S\&SP & Italy & $12 / 09 / 2000$ & N/A & + & 190-591 & FD & DM & \begin{tabular}{|l|}
$10 / 09 / 2001$ \\
\end{tabular} & $\mathrm{R}$ \\
\hline $72 / 2000$ & \begin{tabular}{|l|} 
Pencils \\
\end{tabular} & $\mathrm{CD}$ & China & $23 / 11 / 2000$ & + & + & $735-772$ & FD & $\mathrm{TC}$ & $22 / 02 / 2002$ & \\
\hline $74 / 2000$ & \begin{tabular}{|l} 
Drill bits \\
\end{tabular} & S\&SP & Brazil & $30 / 11 / 2000$ & + & N/A & --- & --- & --- & $31 / 05 / 2002$ & $\mathrm{U}$ \\
\hline
\end{tabular}




\begin{tabular}{|c|c|c|c|c|c|c|c|c|c|c|c|}
\hline & & & & & Injur: & & & ntidumpin & & & \\
\hline $\begin{array}{c}\text { Year of } \\
\text { Presentation }\end{array}$ & Product & Industry & Origin & $\begin{array}{c}\text { Date } \\
\text { Opened }\end{array}$ & Preliminary & Final & $\begin{array}{c}\text { Dumping } \\
\text { Margin } \\
(\%)\end{array}$ & $\begin{array}{c}\text { Duty } \\
\text { Criteria }\end{array}$ & Methodology & $\begin{array}{c}\text { Date Final } \\
\text { Decision } \\
\text { Published }\end{array}$ & Notes \\
\hline $75 / 2000$ & $\begin{array}{l}\text { Quizalofop-p- } \\
\text { ethyl }\end{array}$ & $\mathrm{Ch}$ & Japan & $22 / 12 / 2000$ & $\mathrm{~W}$ & + & 306 & FD & $\overline{\mathrm{DM}}$ & $24 / 06 / 2002$ & \\
\hline 76/2000 & Playing cards & $\mathrm{O}$ & China & $14 / 05 / 2001$ & + & + & $\begin{array}{r}223- \\
2550\end{array}$ & FD & TC & $14 / 11 / 2002$ & \\
\hline $77 / 2000$ & \begin{tabular}{|l|} 
Poliol \\
\end{tabular} & $\mathrm{Ch}$ & United States & $14 / 05 / 2001$ & + & + & -- & FD & $\overline{D M}$ & $14 / 11 / 2002$ & \\
\hline $78 / 2000$ & Chain saw blades & S\&SP & $\begin{array}{l}\text { United } \\
\text { Kingdom }\end{array}$ & $26 / 02 / 2001$ & + & + & --- & -- & -- & $27 / 08 / 2002$ & \\
\hline $81 / 2000$ & Polyester fiber & T\&TP & $\begin{array}{l}\text { Republic of } \\
\text { Korea }\end{array}$ & $21 / 05 / 2001$ & $\mathrm{~W}$ & + & 13 & FD & DM & $14 / 11 / 2002$ & \\
\hline $87 / 2000$ & Ball bearings & S\&SP & China & 04/06/2001 & + & + & --- & FD & $\mathrm{TC}$ & $04 / 12 / 2002$ & \\
\hline $88 / 2000$ & Syringes & P\&PP & $\begin{array}{l}\text { China, } \\
\text { Republic of } \\
\text { Korea }\end{array}$ & $04 / 06 / 2001$ & + & + & \begin{tabular}{l|}
--- \\
---
\end{tabular} & $\begin{array}{l}-- \\
---\end{array}$ & $\begin{array}{l}-- \\
--\end{array}$ & $05 / 12 / 2002$ & \\
\hline 92/2000 & \begin{tabular}{|l|} 
Microwave \\
ovens
\end{tabular} & $\mathrm{CD}$ & China & $14 / 06 / 2001$ & + & + & |59-69 & FD & $\mathrm{TC}$ & $16 / 12 / 2002$ & \\
\hline $100 / 2000$ & Toluene & $\mathrm{Ch}$ & United States & $21 / 06 / 2001$ & + & + & 35 & FD & $\overline{\mathrm{DM}}$ & \begin{tabular}{|l|}
$19 / 12 / 2002$ \\
\end{tabular} & \\
\hline $30 / 2001$ & Plaguicide & $\mathrm{Ch}$ & China & $22 / 08 / 2001$ & $\mathrm{~W}$ & + & $338-433$ & FD & $\mathrm{TC}$ & $26 / 12 / 2002$ & \\
\hline $31 / 2001$ & Air conditioners & $\mathrm{CD}$ & Brazil, China & $22 / 08 / 2001$ & + & + & --- & LD & $\mathrm{TC}$ & $24 / 02 / 2003$ & \\
\hline $51 / 2001$ & $\begin{array}{l}\text { Bathroom and } \\
\text { kitchen faucets }\end{array}$ & S\&SP & China & $10 / 10 / 2001$ & + & + & $230-633$ & FD & TC & $11 / 04 / 2003$ & \\
\hline 53/2001 & \begin{tabular}{|l|} 
Fiber glass \\
\end{tabular} & $\mathrm{P} \& \mathrm{PP}$ & New Zealand & $02 / 10 / 2001$ & + & N/A & --- & --- & -- & $25 / 03 / 2003$ & $\mathrm{U}$ \\
\hline $56 / 2001$ & Pipe accessories & S\&SP & $\begin{array}{l}\text { Brazil } \\
\text { China }\end{array}$ & $10 / 10 / 2001$ & + & + & $\begin{array}{r}106- \\
204\end{array}$ & $\begin{array}{l}\text { FD } \\
\text { FD }\end{array}$ & $\begin{array}{r}\text { DM } \\
\text { TC }\end{array}$ & $11 / 04 / 2003$ & \\
\hline 59/2001 & Tires & R\&RP & \begin{tabular}{|l|} 
China, \\
Indonesia, \\
Thailand
\end{tabular} & $19 / 09 / 2001$ & $+/-$ & + & $\begin{array}{r}85- \\
101\end{array}$ & $\begin{array}{l}\text { FD } \\
\text { FD } \\
\text { FD }\end{array}$ & $\begin{array}{r}\text { TC } \\
\text { DM } \\
\text { DM }\end{array}$ & $21 / 03 / 2003$ & \\
\hline $60 / 2001$ & \begin{tabular}{|l|}
$\begin{array}{l}\text { Stainless steel } \\
\text { tubes }\end{array}$ \\
\end{tabular} & S\&SP & $\begin{array}{l}\text { Brazil, } \\
\text { Taiwan }\end{array}$ & $21 / 11 / 2001$ & + & + & $26-587$ & $\begin{array}{l}\text { FD } \\
\text { FD }\end{array}$ & $\begin{array}{l}\text { DM } \\
\text { DM }\end{array}$ & $20 / 05 / 2003$ & \\
\hline 69/2001 & Glifosato & $\mathrm{Ch}$ & China & $18 / 04 / 2002$ & $\mathrm{~W}$ & + & --- & --- & -- & \begin{tabular}{|l|}
$23 / 09 / 2003$ \\
\end{tabular} & NI \\
\hline
\end{tabular}




\begin{tabular}{|c|c|c|c|c|c|c|c|c|c|c|c|}
\hline \multirow{2}{*}{$\begin{array}{c}\text { Year of } \\
\text { Presentation }\end{array}$} & \multirow[b]{2}{*}{ Product } & \multirow[b]{2}{*}{ Industry } & \multirow[b]{2}{*}{ Origin } & \multirow[b]{2}{*}{$\begin{array}{c}\text { Date } \\
\text { Opened }\end{array}$} & \multicolumn{2}{|c|}{ Injury } & \multicolumn{3}{|c|}{ Antidumping } & \multirow[b]{2}{*}{$\begin{array}{c}\text { Date Final } \\
\text { Decision } \\
\text { Published }\end{array}$} & \multirow[b]{2}{*}{ Notes } \\
\hline & & & & & Preliminary & Final & $\begin{array}{c}\text { Dumping } \\
\text { Margin } \\
(\%)\end{array}$ & $\begin{array}{c}\text { Duty } \\
\text { Criteria }\end{array}$ & Methodology & & \\
\hline $71 / 2001$ & $\begin{array}{l}\text { Cold laminated } \\
\text { products }\end{array}$ & S\&SP & $\begin{array}{l}\text { Kazakhstan, } \\
\text { Republic of } \\
\text { Korea, } \\
\text { South Africa } \\
\text { Ukraine }\end{array}$ & $19 / 07 / 2001$ & + & + & $\begin{array}{r}51- \\
183\end{array}$ & $\begin{array}{l}\text { FD } \\
\text { FD } \\
\text { FD }\end{array}$ & $\begin{array}{l}\mathrm{DM} \\
\mathrm{DM} \\
\mathrm{DM}\end{array}$ & $10 / 01 / 2003$ & \\
\hline $75 / 2001$ & Pork meat cuts & $\mathrm{PF}$ & Brazil & $06 / 11 / 2001$ & $\mathrm{~W}$ & - & $-\ldots$ & --- & --- & \begin{tabular}{|l|}
$01 / 08 / 2002$ \\
\end{tabular} & \\
\hline $77 / 2001$ & PVC & $\mathrm{Ch}$ & \begin{tabular}{|l} 
Mexico, \\
United States
\end{tabular} & $18 / 04 / 2002$ & N/A & + & --- & $\overline{---}$ & --- & $24 / 04 / 2003$ & $\mathrm{R}$ \\
\hline $81 / 2001$ & $\begin{array}{l}\text { Flat steel or iron } \\
\text { products }\end{array}$ & S\&SP & $\begin{array}{l}\text { Australia, } \\
\text { India, } \\
\text { Republic of } \\
\text { Korea, } \\
\text { Russia, South } \\
\text { Africa, } \\
\text { Taiwan }\end{array}$ & $30 / 05 / 2002$ & $+/-$ & + & $\begin{array}{r}28- \\
70\end{array}$ & $\begin{array}{r}\text { FD } \\
-- \\
\text { FD } \\
- \\
\text { FD } \\
\text { FD }\end{array}$ & $\begin{array}{r}\mathrm{DM} \\
-- \\
\mathrm{DM} \\
- \\
\mathrm{DM} \\
\mathrm{DM}\end{array}$ & $27 / 05 / 2003$ & \\
\hline $82 / 2001$ & \begin{tabular}{|l|} 
Bicycle tires \\
\end{tabular} & $R \& R P$ & India & $30 / 05 / 2002$ & + & + & 25 & FD & DM & $27 / 05 / 2003$ & \\
\hline $89 / 2001$ & Wooden hangers & $\mathrm{CD}$ & China & 08/08/2002 & N/A & + & --- & LD & $\mathrm{TC}$ & 23/12/2003 & $\mathrm{R}$ \\
\hline $94 / 2001$ & $\begin{array}{l}\text { Thermos and } \\
\text { similar }\end{array}$ & $\mathrm{CD}$ & China & $29 / 07 / 2002$ & + & + & 586 & LD & TC & $08 / 01 / 2004$ & \\
\hline $10 / 2002$ & Starch & $\mathrm{O}$ & \begin{tabular}{|l} 
European \\
Union
\end{tabular} & $06 / 12 / 2002$ & + & - & --- & --- & -- & $13 / 11 / 2003$ & \\
\hline $43 / 2002$ & $\begin{array}{l}\text { Eviscerated } \\
\text { chicken }\end{array}$ & $\mathrm{PF}$ & Brazil & $26 / 08 / 2002$ & N/A & + & --- & -- & --- & $28 / 02 / 2003$ & $\mathrm{R}$ \\
\hline
\end{tabular}

Jotes: 1.Industry abbreviations are as follows: $\mathbf{S \& S P}=$ Steel and Steel Products; $\mathbf{C h}=$ Chemicals; $\mathbf{T} \& \mathbf{T P}=$ Textiles and Textile Products; $\mathbf{P \& P P}=$ Plastic and Plastic Products $; \mathbf{E E}=$ Ilectrical Equipment; $\mathbf{P F}=$ Processed Foods; $\mathbf{M} \& \mathbf{N E E}=$ Machinery and Non- Electircal Equipment; $\mathbf{W} \boldsymbol{\&} \mathbf{P P}=$ Wood and Paper Products; $\mathbf{R} \& \mathbf{R P}=$ Rubber and Rubber Products; $\mathbf{C D}=$

Jonsumer Durables; $\mathbf{O}=$ Others.

$\therefore$ Dates: $\mathrm{dd} / \mathrm{mm} / \mathrm{yr}$

i. Duty Criteria: FD- Full duty, LD- Lesser Duty

$\therefore$ Methodology: DM- Domestic market, TC- Third country, CB- Cost based

i. Other symbols: $\mathbf{W}=$ without preliminary determination; $\mathbf{N} / \mathbf{A}=$ not applicable; $\mathbf{C}=$ closed; $\mathbf{R}=$ revision; $\mathbf{U}=$ undertaking; ---: not available and, $\mathbf{N I}=$ national interest and case closed without neasures.

iource: Authors's elaboration based on information published by CNCE (www.mecon.gov.ar/cnce), and data provided by the UGE. 


\section{$\underline{\text { Annex } 2}$ : Administrative Procedures in AD Investigations}

Decree 1,326/98 and 1,059/96 include the regulations for administering AD and SG investigations such as administrative requirements to be followed by petitioners, the time periods allowed for different parts of the investigations, and the criteria applied by Argentina when the WTO regulations offers different options. Figure A.1shows the main steps to be followed by the the CNCE and the UGE in AD investigations:

(i) Opening an investigation: Before accepting to process a petition, the UGE ensures that the information provided is complete. On accepting the petition, a copy is sent to the CNCE who prepares reports on three matters: (i) "similar product", (ii) "industry representation" and, (iii) "injury and causation" from dumping to injury. Together with the petition, these reports are used by the UGE to determine whether the evidence supports the presumption of dumping and injury. This evidence is submitted to the Secretary of Industry and Trade who publishes its decision on whether or not to open the case, in the Diario Oficial. Because most of the petitions have ended in an investigation, this stage of the process has not been used to filter cases.

(ii) Arriving at a preliminary determination: After an investigation is opened, the deadline for coming to a preliminary determination on injury and dumping is anywhere from two to four months (Article 26 of Decree 1,326/98). Negative preliminary determinations on either dumping or injury close the case. Nevertheless, in cases where the evidence is insufficient to arrive at preliminary determinations, investigations can continue directly to the final determinations. As shown in Annex 1, close to 1/3 of the investigations were completed without a preliminary determination ${ }^{42}$.

(iii) Arriving at a final determination: AD investigations must be completed within 12 months from the date of initiation but in complex cases, this deadline can be extended by

\footnotetext{
${ }^{42}$ Undertakings are regulated by Chapter 5 of Decree 1,326/98. Annex 1 shows that there has been seven undertakings out of 111 cases.
} 
up to six months ${ }^{43}$. Before final determinations are reached, the CNCE verifies the information that has been presented by national producers, importers and distributors. In contrast, because of insufficient budget, the UGE cannot verify the information that has been supplied by exporters in order to determine the dumping margins.

Final positive injury and dumping determinations result in the introduction of $\mathrm{AD}$ measures. The Minister of Economy, on the basis of the national interest, has the option of refusing to impose the measures recommended by the Secretary of Industry and Trade. As said, this option has been invoked in only one case: glifosato.

\footnotetext{
${ }^{43}$ Article 30 of Decree 1,326/98 establishes that: "El Ministro de Economía y Obras y Servicios Públicos se expedirá al respecto y consecuentemente dictará la resolución final estableciendo o denegando la aplicación de derechos antidumping o compensatorios".
} 


\section{Figure A.1: Flow-Chart of AD Investigation}

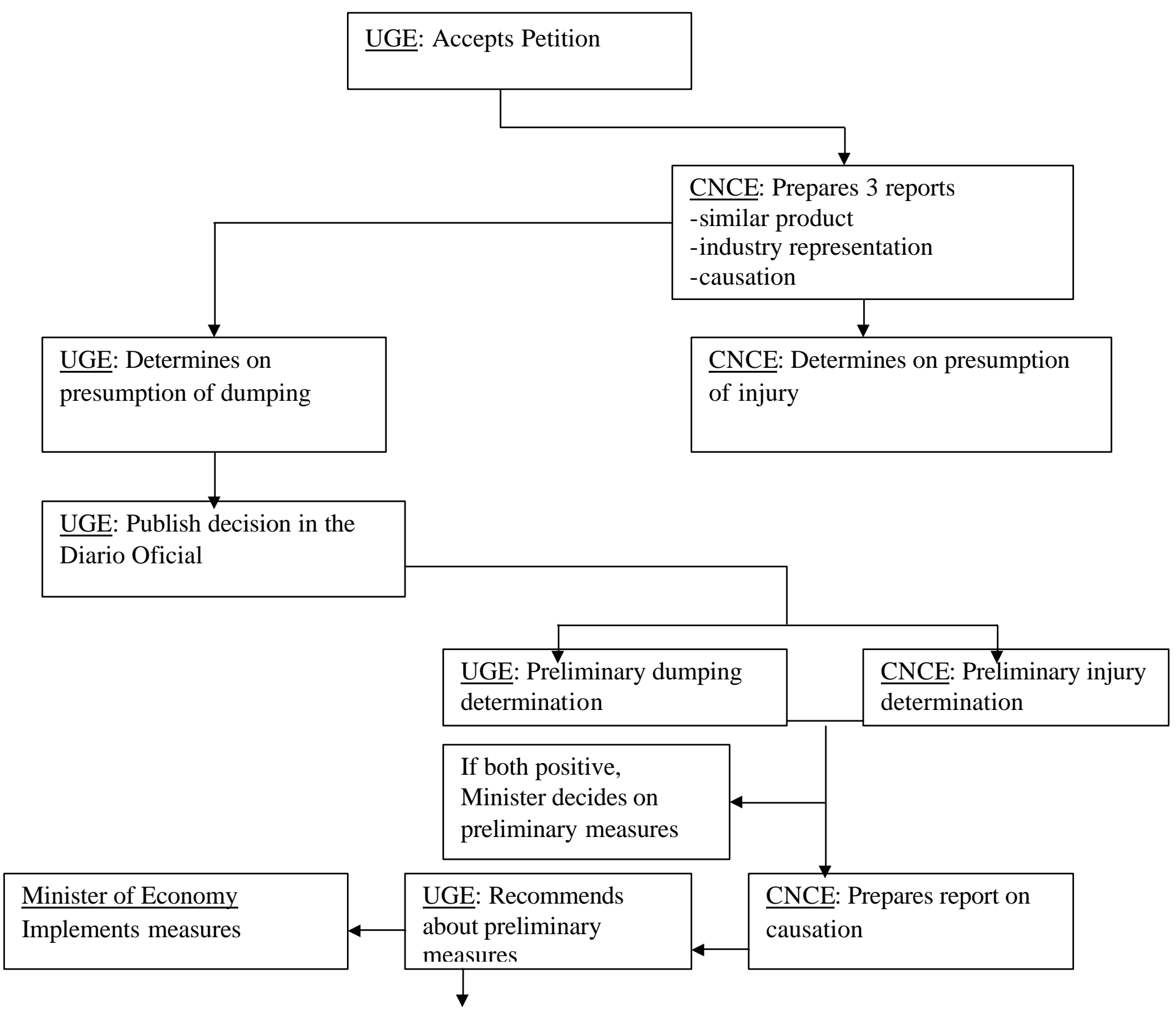

FINAL

Source: Author's elaboration based on Decree 1,326/ 98. 


\section{Acronyms}

- Agreement on Textiles and Clothing (ATC).

- Antidumping (AD)

- Asociación Latino Americana de Integración (ALADI)

- Código Aduanero (CA)

- Comisión Nacional de Comercio Exterior de Argentina (CNCE)

- Common external tariff (CET)

- Countervailing duties (CVD)

- Countervailing measures (CVM)

- Dispute Settlement Body (DSB)

- Free on Board (FOB)

- General Agreement on Tariffs and Trade (GATT)

- Instituto Nacional de Estadísticas y Censos (INDEC)

- Mercosur (Mercado Común del Sur).

- Multi Fiber Agreements (MFA)

- Real exchange rate (RER)

- Safeguard (SG)

- Safeguards Agreement (SA)

- Textile Monitoring Body (TMB)

- U.S. International Trade Commission (ITC)

- Undersecretary of Gestión Comercial Externa (UGE)

- Unión Industrial Argentina (UIA)

- United States of America (US)

- Uruguay Round (UR)

- World Trade Organization (WTO) 